\title{
Only Prometheanism? The policy of the Polish state towards selected circles of the Russian emigration in the years 1926-1935
}

Outline of content: The author sets himself a task of analysing policy of the Polish authorities towards the Russian emigrants in Poland in 1926-1935 and of answering the question in which way that policy differed from the one pursued in the earlier period. He also answers the question of what caused the interest of the Polish authorities in the Russians in the context of Promethean policy.

Keywords: Second Republic of Poland, Savinkov, Pilsudski, Filosofov, Niezbrzycki, intelligence, Prometheism

"Selfless and kind ... are there such people in the West? At the time, Poland decided to offer NTSNP a lot of help without making any conditions. We owe it undying gratitude. Our co-operation with the Poles before the war provided a basis for co-operation during the war". ${ }^{1}$ It was in these rather high-sounding words, forty years after the war, that Arkady Stolypin, a member of the leadership of the National Workers' Union of the New Generation, ${ }^{2}$ a son of Pyotr Stolypin, a famous Russian politician, the author of reforms designed to transform Russia into a liberal empire, thanked the Poles. What did Stolypin really thank for after so many years? This part of his speech became an inspiration for me to research the history of co-operation of Polish authorities with the circles of the Russian emigration in the years 1926-1935, in the context of the Promethean work performed with regard to other peoples of the former empire. This article is an abbreviated presentation of the issues and the first results of this research.

\footnotetext{
${ }^{1}$ А.П. Столыпин, На службе России. Очерки по истории НТС, Frankfurt am Main, 1986, http://ntsrs.ru/content/p-stolypin-na-sluzhbe-rossii (access: 30 May 2014).

21927 - Natsionalny Soyuz Russkoy Molodezhi; 1931 - Natsionalny Soyuz Novogo Pokoleniya; 1937 - Natsionalno-Trudovoy Soyuz Novogo Pokoleniya, hereinafter: NTS.
} 


\section{The beginnings of co-operation}

The first steps towards an agreement with the Russians were taken at the behest of Józef Piłsudski by Karol Wędziagolski, who had been sent to Paris to get in touch with Boris Savinkov and Nikolai Tchaikovsky. ${ }^{3}$ Wędziagolski was chosen because he enjoyed the confidence of both the Chief of State and Savinkov. ${ }^{4}$ The course of the Polish-Russian negotiations, and the emergence of the idea of "the third Russia" was described in a comprehensive manner by Andrzej Nowak in his monograph Poland and the three Russias. I should advise the reader that one of his conclusions was that an agreement with "the third Russia" could have led to the seizure of Moscow by Savinkov only in very favourable conditions, including the capture and holding of Kiev by the Ukrainians, which did not happen after all. ${ }^{5}$ Basing his political and military action on Poland, Savinkov had to accept the right of peoples to self-determination. ${ }^{6}$ We are unable to determine whether he was actually going to observe this right. One can also have serious doubts whether he would be able to force the Russian society into respecting it. ${ }^{7}$ The agreement with Piłsudski also required co-operation with the allies of Poland, i.e. the representative of the Ukrainian People's Republic (UPR), ataman Symon Petlura $^{8}$ and with General Stanislav Bulak-Balakhovich, deliberately manoeuvring at that time between the Belarusian and Russian identity. ${ }^{9}$ Savinkov was the only Russian émigré leader who was willing to co-operate with all anti-Bolshevik forces in order to liberate Russia. That willingness to co-operate and the demarcation of

3 Karol Wędziagolski's letter to Piotr Wandycz, Sao Paulo, 28 December 1964, in: "Rosyjski łącznik Naczelnika - wybór listów Karola Wędziagolskiego do Piotra Wandycza”, ed. A. Nowak, Arcana, 70/71 (2006), pp. 90-91.

4 A. Nowak, Polska i trzy Rosje. Studium polityki wschodniej Józefa Piłsudskiego (od kwietnia 1920 roku), Kraków, 2001, p. 466 (revised edition: 2014).

${ }^{5}$ Ibid., pp. 606-607.

6 The principles of territorial division - the most sensitive issue for both Poles and Russians - were laid out already in the first issue of the organ of the RCP, "Россия и Польша", Свобода of 17 July 1920. In the same vein, Savinkov wrote in another article: "Отделившиеся ныне от России народы, образовавшия новыя государства имеют неоспоримое право на самостоятельное политическое бытие. Не силою орыжия, а лишь по добровольному соглашению может произойти соединение этих народов и будущей Россией через Учредительныя Собрания свои и Учредительное Собрание Русское. [...] Только тем же принципом самоопределения народов может быть разрешен «спор славян между собою» - споры России и Польши”, Б. Савинков, “Чего мы хотим”, Свобода, 1 (17 July 1920).

7 According to Georgi Kutiepov, "He by no means requires from the Russians the recognition of Ukraine”, cf. G. Kutiepov's telegram to Prince Lvov in Paris about Savinkov's talks with J. Piłsudski, Warsaw, 16 June 1920, in: Sasiedzi wobec wojny 1920 roku, ed. J. Cisek, London, 1990, p. 106.

8 A draft of the agreement concluded between the UPR and the RCP in Poland on 18 November 1920, International Institute of Social History (hereinafter: IISH), Boris Viktorovich Savinkov Papers (on-line collection), doc. 138 and 139.

9 Cf. The agreement between B. Savinkov and General Bulak-Balakhovich on the principles of co-operation, Warsaw, 27 July 1920, in: Sąsiedzi wobec wojny, pp. 111-112. 
new borders through holding population plebiscites made Savinkov, in the optics of the Russian public, a controversial person. However, it should be recalled that his co-workers, well-known Saint Petersburg intellectuals, forming the so-called literary triumvirate, i.e. Dmitry Merezhkovsky, Zinaida Gippius and Dmitry Filosofov, were even more radical in their views; they believed that Poland should return to the pre-partition borders of $1772 .{ }^{10}$

Savinkov's activities did not enjoy the support of either the general public in Russia, or Western politicians who preferred to support the "White Movement": Alexander Kolchak, Anton Denikin, and Nikolai Yudenich. Action was able to gain momentum only after the defeat of Denikin and the liquidation of his army in the early spring of 1920, in the Crimea. In mid-June, Piłsudski approved the formation of Russian troops under Boris Savinkov's political control. ${ }^{11}$ At the end of June, the first meeting of the Russian Political Committee (RPC) was held under the leadership of Filosofov, ${ }^{12}$ and on 17 July the first issue of its political organ - Svoboda (Freedom) was published, officially edited by the Merezhkovski's secretary, Vladimir Zhlobin.

On 12 October 1920, contrary to the opinion of the Polish Ministry of Foreign Affairs and Piłsudski's plans, as well as those of the military circles who wanted to give the allies a little more time to prepare for the offensive, a premature, and disadvantageous for the Polish side, truce was signed with the Bolsheviks. ${ }^{13}$

10 "Not prearranging anything, we referred to Poland and the Poles in the same way, and we found ourselves on the same, in detail, positions. The dispute over the «borders», that empty, reprehensible and fundamentally absurd dispute, equally outraged us. When Dima [Filosofov] first printed at Gzowski's that the notorious borders of 1772 meant nothing else but justice, it was as if we all had signed our names under this", Z. Gippius, Dzienniki petersburskie. Dziennik warszawski, translated and edited by H. Chłystowski, Warszawa, 2010, p. 446.

11 A. Nowak, Jak rozbić rosyjskie imperium. Idee polskiej polityki wschodniej (1733-1921), Warszawa, 1991, pp. 263-265. General Boris Piermykin ultimately became the commander of the 3rd Army formed in Poland, which was subordinated, from the military point of view, to General Pyotr Wrangel. The first point of the agreement signed by B. Savinkov, D. Filosofov and Lieutenant General P. Glazenap read: "A separated Russian Unit formed on the territory of the Republic of Poland operates in close moral relationship with General Wrangel. For the time being, however, it operates completely autonomously", The principles of co-operation between the Russian Political Committee and the command of the Russian troops formed in Poland, Warsaw, 7 July 1920, in: Sasiedzi wobec wojny, p. 107.

12 The committee members included: Chairman Savinkov, Deputy Chairman Dmitry Filosofov, Dmitry Merezhkovsky, Zinaida Gippius, Alexandr Dickhoff-Derenthal, Nikolai Bulanov, Boris Hoershelman, Dmitry Odiniec, Fyodor Rodichev, Viktor Savinkov - Boris's brother, V. Ulyanitsky, Viktor Portugalov; Z. Gippius, Dzienniki petersburskie, p. 439; R.B. Spence, Renegade on the Left, New York 1991, p. 269; В.К. Виноградов, В.Н. Сафонов, Борис Савинков противник большевиков in: Борис Савинков на Лубянке. Документы, ed. А.Л. Литвин, Москва, 2001, p. 7.

13 J. Borzęcki Pokój ryski 1921 roku i kształtowanie się międzywojennej Europy Wschodniej, Warszawa, 2012, pp. 212-221. The author exhaustively discusses the conditions and circumstances under which the armistice was signed. 
The stake that Piłsudski probably played for was only the lands of eastern Belarus and, to a lesser extent, Kiev, but capturing it and holding it depended then only on the Ukrainians, and their forces were insufficient. ${ }^{14}$ It was a shocking message for the Russians. ${ }^{15}$ Apart from the independent units of Balakhovich, Yakovlev and Salnikov (incidentally, these units were not ethnically uniform Russian troops), the 3rd Army did not take part in combat since it was not yet sufficiently organized and equipped. The truce meant that the combined Russian-Cossack-BelarusianUkrainian forces would have to continue their combat without the support of the Polish Armed Forces, which minimized the chance of success. Balakhovich and Savinkov's solitary offensive in Belarus, and Piermykin and Petlura's towards the Crimea, quickly collapsed. By early December, all the troops that had managed to cross the Polish border, where they were sent to internment camps, returned. ${ }^{16}$ These events took place a little later than the evacuation of General Wrangel's troops from the Crimea to the Balkans. Thus, the last serious attempt to incite counter-revolution collapsed.

The RPC's reputation began to fall rapidly, which manifested itself even if in the change of its name to the Russian Evacuation Committee (REC). Seeking a way out of the situation, Savinkov was forced to make more and more concessions to other nations. It is evidenced by the draft of an agreement to create a Union of States on the territory of the former Russian Empire, the recognition de jure of Estonia, Latvia, Georgia (interestingly, the draft makes no mention of Lithuania, whose fate was not yet settled due to the functioning of Central Lithuania) ${ }^{17}$ and the agreement with the UPR, under which its independence and the government

${ }^{14}$ I agree with the opinion of Andrzej Nowak and Joanna Gierowska-Kałłaur that in Piłsudski's concept Balakhovich and Savinkov's joint action was primarily aimed to recapture the lands of eastern Belarus from the hands of the Bolsheviks, which Savinkov was not quite aware of; Nowak, Polska i trzy Rosje, pp. 606-607; J. Gierowska-Kałłaur, "Straż Kresowa wobec kwestii białoruskiej. Deklaracje i praktyka”, Studia z Dziejów Rosji i Europy Środkowo-Wschodniej, 44 (2009), p. 32. On the Polish side, in October 1920, no wide-range action, such as e.g. the issue of a march on Moscow raised in journalism, could be taken into account. Piłsudski, as well as Savinkov, and even Wrangel, mainly due to Lloyd George's policy (France was, in fact, forced to seek rapprochement with London, and could not pursue a fully independent Eastern policy), lost the chance to obtain the military support of the West, which sought agreement with the new Bolshevik power; A. Nowak, Pierwsza zdrada Zachodu. 1920 - zapomniany appeasement, Kraków, 2015, pp. 467-468.

15 Savinkov's close associates, Gippius and Merezhkovsky, until recently extolling the Chief of State in the brochure Józef Piłsudski as the "saviour of mankind", left for France in October 1920 with a sense of betrayal, which was one of the causes of their conflict with Filosofov, who decided to continue operations in collaboration with Poland, Gippius, Dzienniki petersburskie, p. 465.

16 Z. Karpus, Wschodni sojusznicy Polski w wojnie 1920 roku. Oddziały wojskowe ukraińskie, rosyjskie, kozackie i białoruskie w Polce w latach 1919-1920, Toruń, 1999, p. 175.

17 IISH, BVSP, the Draft of the agreement between the Government of the UPR and the RPC on the "Union of States" to be established on the territory of the former Russian Empire, 23 February 1921 , doc. $137-138$. 
headed by Petlura were recognized. This draft agreement was signed on 17 March 1921 by the representatives of both parties, on the eve of the conclusion of the Polish-Soviet peace treaty in Riga; it sustained the arrangements of the convention concluded between the RPC and the UPR of 18 November $1920 .{ }^{18}$ In addition, in early January, a secret meeting of the REC was held, where it was decided to re-launch the People's Union for the Defence of Homeland and Freedom, create an information office at it, and to convene in July 1921 a congress of anti-Bolshevik organizations, to which, importantly, the non-Russian peoples of the empire were invited. ${ }^{19}$

The opening of a new chapter of the Polish-Russian co-operation was hampered by the provisions of the Treaty of Riga, where both parties undertook not to provide shelter or support political movements affecting the independence or constitution of either party. ${ }^{20}$

Contrary to the clauses of the Treaty of Riga, representatives of anti-Bolshevik movements did not leave Poland. On the contrary, the headquarters of the REC at 68, Marszałkowska st. in Warsaw hosted a convention of anti-Bolshevik organizations on 13-16 July 1921. According to Russian researchers, 140 activists turned up, including as many as fifty from Bolshevik Russia. ${ }^{21}$ Among them were also representatives of Ukrainian organizations, the head of the Ukrainian Military Mission, General Viktor Zelinski, Belarusian, Cossack, and probably Georgian organizations, and others. The convention was also attended by Poles, including Marshal Piłsudski's envoy, Colonel Bolesław Wieniawa-Długoszowski, the order officer at the Chief of Staff, General Stanisław Dowoyno-Sołłohub, ${ }^{22}$ and representatives of several embassies: British (Secret Intelligence Service agent, Sidney Reyly, and Lieutenant Colonel Emilius Clayton, a member of the military mission), French, Belgian, Italian and American. ${ }^{23}$ The participants in the convention stressed the need for co-operation among the nations of the former empire with the aim to create "the third Russia" - one respecting the rights of other nations and historic states. They also decided to engage in co-operation only with the states of the Entente, excluding one with the Germans, who - in the opinion of the delegates - were natural enemies of Russia. ${ }^{24}$ The activity of anti-Bolshevik organizations was possible thanks to the acquiescence of Marshal Piłsudski, who was taking into

18 IISH, BVSP, the Minutes of the joint meeting of representatives of the RPC and the government of the UPR on the conclusion of a co-operation agreement, February 1921, doc. 139.

19 Spence, Renegade, p. 269; Виноградов, Сафонов, Борис Савинков, p. 10.

20 Article V of the peace treaty between Poland and Russia and Ukraine, with attachments, Riga, 18 March 1921, Dokumenty z dziejów polskiej polityki zagranicznej 1918-1939, eds. T. Jędruszczak, M. Nowak-Kiełbikowa, vol. 1, Warszawa, 1989, p. 155.

21 Виноградов, Сафонов, Борис Савинков, р. 11.

22 Ibid., p. 11.

23 Spence, Renegade, p. 299.

24 Протокол решений съезда “Союза защиты и свободы Родины”, in: Борис Савинков на Лубянке, рр. 500-503. 
account the possibility of resumption of war in the spring of 1921, and the use of these forces, ${ }^{25}$ which, however, collided with the policy of the government of the Republic of Poland that wanted to observe their treaty obligations, and pressed for the liquidation of armed White Guard troops operating near the border with Bolshevik Russia, and for the expulsion of their leaders. ${ }^{26}$

The convention mentioned above provoked a lively response on the part of the Bolsheviks, who all the more energetically began to demand the expulsion of the "White Guards". The pressures of the Polish government caused that, at the end of October, Savinkov with some of his associates had to move to Prague (leaving Poland, he did not hide his grudge towards the Poles). ${ }^{27}$ Dmitry Filosofov, who, after all, soon returned to Poland (in the years 1921-1924, he served as director of the Polish branch of the People's Union for the Defence of Homeland and Freedom), did not avoid a forced departure. In subsequent years, efforts were made to expel only those persons who were hostile to Poland, while giving formal satisfaction to the Soviet Union, which insisted, following the assassination of polpred (plenipotentiary representative) Pyotr Woykov and an attempt on the life of Alexei Lizarev, that the Polish state remove anticommunist activists from its borders. ${ }^{28}$

Despite the expulsion of the main leaders of anti-Bolshevik organizations, the Second Department of the General Staff, dominated by Piłsudski's subordinates, did not lose touch with the Russians. A special advocate of co-operation with Savinkov's organization was the chief of the Second Department, Lieutenant Colonel Ignacy Matuszewski, who, in November 1920, wrote: "Having influence on the energetic, fair Russian group provides us with an opportunity for equally

25 T. Snyder, Tajna wojna. Henryk Józewski i polsko-sowiecka rozgrywka o Ukrainę, Kraków, 2008, pp. 38-39; in the first half of 1921, the use of the forces remaining at Savinkov's disposal was also considered in a similar way; Report of the Chief of Defence of the Second Department of the General Staff, Major Terlecki to the Supreme Command of the Polish Armed Forces, including a plan of a military action of B. Savinkov and S. Pelura's troops on the territory of the USSR, 08 May 1921, in: Dokumenty i materialy do historii stosunków polsko radzieckich (hereinafter: D\&M), vol. 4, eds. T. Cieślak, I.A. Khrienov, Warszawa, 1965, pp. 17-19.

${ }^{26}$ A letter from the Ministry of Foreign Affairs of the Republic of Poland to the Polish Diplomatic Mission in Paris on the expulsion of Savinkov's supporters from Poland, Warsaw, 8 October 1921, in: D\&M, vol. 4, pp. 87-92.

27 Spence, Renegade, p. 316.

${ }^{28}$ It is interesting that among the Russians involved in the assassination of Pyotr Voykov there was also a later participant in the resistance movement, murdered during the war by the Gestapo in Warsaw, A. Pawlukiewicz, and an agent of the Second Department, Mikhail Yakovlev, who organized, among others, weapons for Boris Koverda; Boris Koverda's account, http://zhurnal. lib.ru/g/gorbunow_g_a/koverda.shtml (access: 5 May 2015); A.S. Kowalczyk, Warschau: Die Russich Emigration in Polen in: Der grosse Exodus. Die russische Emigration und ihre Zentren 1917 bis 1941, hrsg. K. Schlögel, Munich 1994, pp. 210-211. Neither of them ever suffered any consequences, as opposed to those unrelated to the matter, yet causing problems to the Polish state, i.e. Ataman Derkach (W. Adamowicz) and the editor of Utro, A. Romashev; М. Яковлев, “К выселению русских эмигрантов из Польши”, Новая Россия, 28 August 1927, no. 41, p. 3. 
painful intervention in the opponent's internal affairs. Only keeping this asset in our hands will force the opponent, without declaring war on them, to adhere to Article II of the preliminaries. By means of successfully carried out reorganization and the strengthening of the Socialist Revolutionary Party, the most dangerous today moment of unification of Russian society, regardless of their social views under the leadership of the Communist Party, as Russia's Representative, will be prevented [emphasis mine - ŁD]". ${ }^{29}$ Matuszewski also considered Savinkov's ideologically destructive activity and his declaration of "abandoning the idea of superpower Russia" to be particularly advantageous for Poland. ${ }^{30}$

The activity of the People's Union was ended after the sending of a letter from the Lubyanka by Savinkov (at the beginning of 1924, as a result of a provocation, he went to the Soviet Union, where he was arrested), ${ }^{31}$ in which he urged Filosofov to recognize the Bolshevik rule. ${ }^{32}$ Filosofov presented an account of the whole matter to the Marshal during a personal visit to Sulejówek, keeping his confidence. ${ }^{33}$ In 1923, the Second Department also ended co-operation with the sabotage-intelligence organization "Wilk" ["Wolf"], created by Boris Savinkov, and led by his brother Viktor. The reason was the conflicts between the Second Department and the Ministry of Foreign Affairs, the poor appraisal of the activity of the Russians, and numerous arrests (only in the years 1921-1922, the Cheka arrested 500 intelligence agents). ${ }^{34}$ At that time, Filosofov was already

${ }^{29}$ From the report of the representative of the General Staff, Lieutenant Colonel I. Matuszewski on the briefing with Polish military attachés in Latvia and Estonia regarding the guidelines for dealing with Soviet Russia, Riga, 19 November 1920, in D\&M, vol. 3, eds. N. GąsiorowskaGrabowska, I.A. Khrienov, Warszawa, 1964, pp. 527-528.

30 A memorandum of the chief of the Second Department of the General Staff, I. Matuszewski, on the use of B. Savinkov and S. Pelura's group in an anti-Soviet action, Warsaw, April 1921, in: D\&M, vol. 4, pp. 15-16; A Report of the Agency of the Second Department of General Staff in Lviv to the Supreme Command of the Polish Armed Forces containing the principles of co-operation with V. Savinkov's intelligence agency, Lviv, 19 July 1921, in: D\&M, vol. 4, pp. 27-30.

31 According to Mikhail Heller, already in December 1921, more or less consciously, Savinkov could be a Soviet agent of influence who, for patriotic reasons, undertook a game with the Bolsheviks, without being aware that he was actually just their pawn. On 10 December 1921 in London, he had a conversation with Leonid Krasin, a close associate of Lenin, who, soliciting in the West for the official recognition of the Bolshevik power and for loans to it, presented a false picture of Bolshevik Russia as an actually liberal state. Thus misled, Savinkov passed on this information to a number of important European politicians, including Piłsudski; M. Heller, List Borysa Sawinkowa do marszałka Piłsudskiego, eds. J. Karpiński, I. Lasota, Wrocław, 1989, pp. 83-84.

32 J. Czapski, Swiat w moich oczach, Ząbki-Paris 2001, p. 143.

33 D. Filosofov to B. Savinkov, Warszawa, 16 September 1924, in: “Из переписки Д.В. Философова. 1920-1932”, Наше Наследие, 2002, nos. 63-64, http://www.nasledie-Rus'.ru/podshivka/6407. php (access: 14 January 2015); Czapski, Świat, p. 144.

${ }^{34}$ K. Paduszek, Polski wywiad wojskowy na Rosje Sowiecka/Zwiazek Sowiecki w latach 1921-1927, Warszawa, 2014, pp. 300-305, a typescript of the doctoral dissertation in the Library of the Historical Institute of Warsaw University. 
the leader and major proponent of co-operation between the Russian emigration and the Polish state. ${ }^{35}$

\section{The Marshal's Return - Prometheanism and the Russian question}

The coup of May 1926, on the one hand, roused hopes among the Russians that their fate would improve, ${ }^{36}$ and on the other - especially among the activists in exile - to exacerbate the relations with the Soviet Union. ${ }^{37}$ Meanwhile, Piłsudski was not going to take a sharp anti-Soviet course. The desire to conclude treaties, in accordance with the policy of balance, both with the Soviet Union (1932 - a non-aggression treaty) and the German Reich (1934 - a declaration of non-

${ }^{35}$ Following the loss of his close associates, he thus justified the fact of his stay: "Future historians will be willing to feel our struggle with the Bolsheviks in terms of a conflict between the Russians and the Poles. Such simple dialectics presents a falsely tortuous and complicated conflict, which led to my decision to stay in Poland and fight alongside Boris Savinkov and the Poles", J.S. Durrant, Borys Sawinkow w Warszawie - z pamiętników D.W. (the article and diary Moy Put' is in Durrant's collection), a copy of the typescript of the dissertation was made available to the author by Professor Andrzej Nowak. In a letter from Yugoslavia of 1921, he wrote: "My stay in Poland - those were my best years, I did what I wanted to do, not what I felt like doing", J. Czapski, Wyrwane strony, Warszawa, 2010, p. 75. Karol Wędziagolski wrote about him: "He became soaked through in the romance of the new era in Polish-Russian relations", K. Wędziagolski, Pamiętniki, wojna i rewolucja, kontrrewolucja, bolszewicki przewrót, warszawski epilog, Warszawa, 2007, p. 429.

36 Виленское Утро, 1660 (16 Мау 1926); ibid., 1662 (18 Мау 1926); За Свободу!, 121 (27 Мау 1926); М. Арцыбашев, “Обезьяна о человеке”, За Свободу! 128 (06 June 1926).

37 The Leadership of the Russian All-Military Union (ROVS), still misinformed by the MOCR, counted on an imminent outbreak of the anti-Bolshevik uprising; in 1927 and 1928, there were attacks on polpred [plenipotentiary representative] Pyotr Woykov and the commercial representative Alexander Lizariev, the transfer of Russian underground publications to the Soviet Union increased, and the secret organizations in the Eastern Borderlands intensified their actions. Future positions were even divided: "This proposal [at a meeting of the Vilnius Russian Society - VRS] was put forward by Gavrilov, who declared that Russian people must be properly prepared for the coup that is to take place in Russia after six months. At the same time, he remarked that after the collapse of the power of the Soviets Vilnius would belong to Russia, and the Board of the VRS would become the first temporary administration of Vilnius region and other lands, which now belonged to Poland, and would be returned to Russia. [...] at the moment of taking power by Russia, the monarchist Russkoye Narodnoye Obyedinyenye would not play any role, because its members were recruited mostly from among Polish citizens", Archives of Modern Records in Warsaw (Archiwum Akt Nowych, hereinafter: AAN), the Ministry of Internal Affairs (hereinafter: MSW), Ref. no. IV/78, Report on the life of national minorities for January, February and March 1929, Warsaw, 1929, p. 21. In Western European emigration press there were rumours about the allied offensive planned for the summer of 1930 and aimed to liberate Russia from the Bolsheviks; P. Kropp, Sekrety wywiadu francuskiego, Warszawa, 1999, pp. 381-382. The disappearance (liquidation by the OGPU - Joint State Political Directorate) of General Alexander Kutepov undermined the hopes of the Russians. 
violence), left no much room for offensive actions. ${ }^{38}$ We would look in vain, after 1926, for actions similar to those of the first half of the 1920s, when sabotage actions were not only planned, but also carried out (General Yuriy [Yurko] Tyutyunnyk's winter march). ${ }^{39}$ After 1926, the support for both the Russians and Promethean peoples was limited to legal addresses, and was of defensive nature. ${ }^{40}$ According to Paweł Libera, following the signing of the non-aggression pact with the Soviet Union in 1932, the Promethean movement was even in a crisis, which lasted until its reform in $1935 .{ }^{41}$

After the liquidation of Savinkov's organization in the first half of the 1920s, apart from his close associate Filosofov and a handful of his followers there was no Russian centre of anti-imperial nature opting for even limited co-operation with the Promethean nations, and accepting the Polish eastern border. ${ }^{42}$

Moreover, at the turn of 1926 and 1927, the inspirational scandal of Soviet intelligence code-named "Trust" was uncovered. According to one version, advocated by three officers of the Second Department, the uncovering of the mystification was to take place following Piłsudski's personal intervention, who became interested in the matter already in July 1926. He instructed the organization "Trust", through Major Janusz Iliński, deputy Polish military attaché in Paris, to obtain the Soviet plans of guard and concentration, upon the reception of which he ultimately ordered to break off co-operation..$^{43}$ Due to the spectacular fiasco of

38 M. Kornat, "Idea prometejska a polska polityka zagraniczna (1921-1939/1940)", in: Ruch prometejski i walka o przebudowę Europy Wschodniej (1918-1940), ed. M. Kornat, Warszawa, 2012, pp. 55-59.

39 Snyder, Tajna wojna, pp. 38-39.

40 P. Libera, "Ewolucja ruchu prometejskiego w okresie międzywojennym", in: Ruch prometejski, p. 226-227.

41 Ibid., pp. 227-229.

42 The border determined in the Treaty of Riga was unacceptable not only for the exile centre or right, but also for the leftist or liberal leaders such as Alexandr Kerensky, Vladimir Burtsev, Pavel Milyukov or even Mark Vishnyak; Kornat, Idea prometejska, p. 44; M. Vishnyak, Years of Emigration 1919-1969, Paris-New York, 1970, p. 67.

${ }^{43}$ W. Michniewicz, Wielki Bluff sowiecki, Chicago, 1991, pp. 245-250; W.T. Drymmer, "Trust", Kultura, 11/217 (1965), p. 102; R. Wraga, “Trust”, Kultura, 4/21-22 (1949), p. 175; also Sergey Voytsiekhovsky, providing this information after Wraga, did not rule out Piłsudski's participation; С.Л. Войцеховский, Трест. Воспоминания и документы, Канада 1974, p. 98; more on the circumstances of the termination of co-operation with the Russians: A. Krzak, Czerwoni azefowie: afera "MOCR-Trust" 1922-1927, Warszawa, 2010, pp. 124-126. The views of researchers on Piłsudski's role in the uncovering of the inspirational operation are divided (the list of literature concerning the operation Trust has several hundred items - studies, monographs and articles - and it is because of the inability to refer to all of them that we are going to focus only on the most recent works of Polish historians). Both Konrad Paduszek and Marek Swierczek claim that the memories of the "Seconds" [members of the Second Department which was also called "Dwójka", i.e. "two" in Polish] were supposed to serve the mythologisation of the person of the Marshal, while Andrzej Pepłoński and Wojciech Włodarkiewicz follow the version presented by the former officers of the "Second", highlighting the Marshal's 
the Second Department, inspired from 1921 by the Soviets, its the then chief, Lieutenant Colonel Tadeusz Schaetzel, was responsible for the termination of co-operation with "Trust". According to one thesis, he had an argument with the Marshal on "Trust"; it is believed that it could have been the reason for his leaving the position of the chief of the Second Department and being transferred in February 1929 to serve in the Ministry of Foreign Affairs. ${ }^{44}$

Despite the significant differences in the views on the shape of future Russia between the Russian emigration and the Promethean nations, and the embarrassment of the former as a result of the "Trust" scandal, the Polish authorities maintained both directions of co-operation. However, they became more distrustful of the Russians and began to look for other sources of intelligence, shifting the burden of co-operation to the "Promethean" nations and the open-source intelligence conducted by military attachés (no co-operation with any organization operating in the USSR was risked any more).

The attitude of the Promethean movement to the Russian emigration in the policy of the Polish state could be compared to the aorta and a thin vein, which if cut, could result in the bleeding of the whole organism to death. By this I mean the need for co-operation, and even if it was only to bring meagre results, it would allow to retain some control over both streams, weakening the pro-German and pro-Soviet currents. Year by year, both of them gained more and more influence among the Promethean nations and Russian émigrés, a noteworthy example of

personal participation in the uncovering of the Soviet operation; Paduszek, Polski wywiad, p. 332; M. Świerczek, "Udział Wiktora Tomira Drymmera w aferze MOCR-Trust w świetle jego artykułu z 1965 r. pod tytułem Trust. Wstęp do analizy", Przegląd Bezpieczeństwa Wewnętrznego, 10 (2014), pp. 165-166; A. Pepłoński, Wywiad polski na ZSRR 1921-1939, Warszawa, 1996, pp. 284-285; W. Włodarkiewicz, Przed 17 września 1939 roku. Radzieckie zagrożenie Rzeczypospolitej w ocenach polskich naczelnych władz wojskowych 1921-1939, Warszawa, 2002, p. 63. In my opinion, any possible order to cease co-operation in December 1926 could not be executed immediately, since the termination of such a complicated operation required some time. In April 1927, the Soviets decided to reveal the operation (for the purposes of further misinformation), probably realizing that Polish intelligence no longer trusted "Trust", R. Wraga, "O szpiegach prowokatorach i naiwnych emigrantach", Wiadomości, 806 (1961). This thesis is supported by the fact that already on 27 May 1927 a proposal of a similar operation directed against the USSR was put forward in Agency no. 2. Therefore, it is impossible that the Second Department began to withdraw from the co-operation with "Trust" only in April 1927; cf. the content of the proposal: W. Stanisławski, Myśl polityczna emigracji rosyjskiej w II Rzeczpospolitej: interpretacje przeszłości i koncepcje polityczne, a typescript of the doctoral dissertation in the Library of the Historical Institute of Warsaw University, p. 263, fn. 173. Unfortunately, due to the lack of access to the full documentation, and even a monograph that would compile all of the available source material and the extensive literature on the subject, it is impossible to formulate a definitive answer to the question of Piłsudski's role in the uncovering of the operation "Trust"; however, because of the weight he attached to this type of activities, it cannot be ruled out that it was significant. It seems, however, that the uncovering of the operation took place before April 1927.

${ }^{44}$ M. Kornat, “Tadeusz Schaetzel (1891-1971), nota biograficzna”, Pressje, 10, no. 22-23, p. 98. 
which was the movement of Russian fascists developing in Germany and the Far East, and Alexander Kazem-Bek's Mladorossi. ${ }^{45}$

That vein was primarily Filosofov's group, who also attracted the supporters of the Novopokolentsy until the outbreak of the world war operating mainly with the support of the authorities of Yugoslavia, and with the approval of the services of Poland and $\operatorname{Japan}^{46}$ (there were also other anti-communist Russian groups, whose activity was tolerated until the early 1930s despite their anti-Polish attitude). Filosofov had a unique position in the Russian circles because of his familiarity with the Chief-of-State. In the years 1920-1926, as he recalled, they had about fifteen talks at the audiences in Belweder Palace and meetings in Sulejówek; ${ }^{47}$ among all Russian immigrants, he was one of the few, and perhaps the only one, whom the Marshal trusted. ${ }^{48}$ After Piłsudski's death, in response to Filosofov's letter of condolence, Tadeusz Schaetzel wrote: "Of those of non-Polish nationality, you are in the first rank of those who are standing at his coffin and can feel close to him". ${ }^{49}$ In the eyes of emigrants, Piłsudski was generally regarded as being anti-Russian, ${ }^{50}$ while Filosofov, breaking simple clichés, saw an ally in him: "Strange to say [...] but Polish anti-Moscovites like in Russia what we like, and hate in it what we hate". ${ }^{51}$ Among the many Poles whom he met in 1920, there were also Tadeusz Schaetzel, Walery Sławek, Bogusław Miedziński, Roman Knoll, Karol Wędziagolski, Stanisław Stempowski, possibly even Tomasz Arciszewski and, according to Wojciech Stanisławski, through Szymon Askenazy, also Józef Beck, Bolesław Wieniawa-Długoszowski ${ }^{52}$ and, perhaps, Tadeusz Hołówko, whom he had

45 AAN, MSW, Ref. no. IV / 95, Report on the life of national minorities for the second quarter of 1934, Warszawa, 1934, p. 46.

46 В.М. Байдалаков, Да возвлечится Россия. Да гибнут наши имена... Воспоминания председатела НТС 1930-1960 г2., Москва, 2002, р. 15.

47 P. Mitzner, Warszawski krag Dymitra Fiłosofowa, Warszawa, 2015, p. 179.

${ }^{48}$ He handed over to Piłsudski a packet of letters from arrested Savinkov; the Marshal apparently did not believe in his betrayal, and the whole matter did not strain his confidence in Filosofov; Czapski, Świat, p. 143; B. Miedziński also recalled the trust that the Marshal had in him, cf. J.S. Durrant, Zapomniany warszawianin, the typescript in the archives of Kultura, in Maisons-Laffitte, fol. 11.

49 Cit. after: W. Stanisławski, “'Rycerz przegranej sprawy’? Kontakty Dymitra Fiłosofowa z polskimi elitami kulturalnymi”, in: Emigracja rosyjska losy i idee, eds. R. Bäcker, Z. Karpus, Łódź, 2002, p. 317.

50 Emigrants could not forgive Piłsudski the Kiev Offensive in the spring of 1920, the purpose of which was to establish independent Ukraine. The plan was widely considered as an attack on Russia, along with the silent acknowledgement of the tsarist officers' being right, who, at the call of General Brusilov, for patriotic reasons, began to join the ranks of the Red Army en masse in order to defend the idea of holy Russia. It was then, as noted by Alain Besançon, that Russian nationalism merged with communism; A. Besançon, Święta Ruś, transl. Ł. Maślanka, Warszawa, 2012, p. 109.

${ }^{51}$ Quoted after W. Stanisławski, “Warszawski Rosjanin”, Tworczość, 58 (1996), no. 4, p. 163; his article from 1931 was kept in a similar vein; Д.В. Филосо́фов, “Белведер”, За Свободу!, 13 (15 January 1931), p. 2.

52 Stanisławski, Myśl polityczna, p. 327. 
a chance to meet in the next few years. ${ }^{53}$ As we can see, in the circle of Filosofov's acquaintances there were leading Polish Promethean activists (Schaetzel, Knoll, Stempowski, Hołówko), as well as Ukrainian and Georgian ones, with whom he maintained sporadic contact, even on the occasion of the nineteenth anniversary of the establishment of the UPR army in May 1927, or at the ball of Ukrainian students in February 1926. ${ }^{54}$

\section{Military and civilian state institutions in co-operation with the Russians}

The main burden of co-operation with the Russians lay with the Second Department of the General Staff, including the officers of Division "East", which I will discuss further below. The Russians were also under the surveillance of employees of the "Ethnic" Division of Agency no. 2 of the Second Department of the General Staff. Its main task was to implement Promethean work among the non-Russian peoples of the USSR..$^{55}$ The department conducted preparatory and sabotage work, to this end supporting various organizations founded by emigrants from the USSR (except the Russian ones). ${ }^{56}$ The surveillance of officers holding diplomatic posts pointed to the need to maintain extreme caution with regard to the Russians, who could be useful only in counter-intelligence work. ${ }^{57}$ Efforts were also made to discourage Japanese intelligence from this co-operation, as evidenced by a fragment of encrypted correspondence from the post "Cholski" of January 1935 "Admittedly, the inside of the 'Cherry Blossom' [Japanese intelligence] is infested with the parasite 'White moth' [white emigration], therefore, an action should be taken by the 'metowcy' [officers of the Second Department remaining in the Far East] with the aim to make the Island aware of the dangers of the White moth's participation itself". ${ }^{58}$ An equally important issue, in addition to the penetration of "white" organizations by Soviet intelligence, was their views on the future of

53 E. Wiszka, Emigracja ukraińska w Polsce 1920-1939, Toruń, 2004, p. 209.

${ }^{54}$ Ibid., pp. 193-194, 209; of the younger generation of the Prometheans, he met Jerzy Giedroyć; Czapski, Świat, p. 142.

55 The Archive of the Institute of National Remembrance in Warsaw (hereinafter: AIPN) BU 1572/1017, Employees of Agency no. 2 of the Second Department of the General Staff. Communication no. 5 of the Main Directorate of Information of the Ministry of Defence, fol. 6.

56 AIPN BU 1572/1165, the Second Department of the General Staff of the Polish Armed Forces, Division "East" in the years 1929-1939 - organization, personnel, records. The co-operation with British intelligence. Developed by Colonel Gajewski of the Main Directorate of Information of the Ministry of Defence, lists of foreign posts, fol. 146.

57 AIPN BU 2602/1440, the Second Directorate of the General Staff of the Polish Armed Forces in Warsaw, Portfolio I, the activity of the Second Department of the General Staff in the years 1933-1939, reports, fol. 272.

58 Ibid., fol. 352. 
Russia, which was to remain undivided, with autonomies for some nations as a last resort. This required the constant monitoring of emigrants trying to fight the Prometheans: "Both Russian politicians in exile and the Soviet ones attempt to paralyse the action of separatists". ${ }^{59}$

A considerable part of the Promethean action was also conducted by civilian institutions, including the personnel of ministries who often had the experience of work in the Second Department. There is evidence that some of them were also interested in co-operation with selected Russian circles such as Filosofov's circle, that of the Novopokolentsy, and even more broadly Eurasianists. Such co-operation was attempted with Sergey Voytsiekhovsky, sympathising with the Eurasian movement, the author of the article "Polska a Eurazja" [Poland and Eurasia], published in the second issue of Droga of 1928, by offering him, at the beginning of 1928, a meeting with professors Marian Zdziechowski and Jan Kucharzewski at the Eastern Institute. Also, the Russians living in Poland were interested in co-operation with the Polish authorities themselves, as evidenced by the figure of a young activist of the "Vilnius Eurasian Group", Andrei Surkov, who sought to reinterpret the Eurasian doctrine so that it could be acceptable to the other peoples of Russia. ${ }^{60}$

59 “Its [emigration's] attitude to the issue of separatism is generally hostile, however, in this respect there is surprising unanimity in the emigration camp, regardless of the differences in political beliefs, concepts of rebuilding the future Russian state, and so on. There are naturally some minor differences depending on the political direction, however, in this respect, as I said, complete unanimity generally prevails. Emigration does not want to hear about a division of future Russia and about even the slightest diminishment of its territories, preaching the idea of 'Yedinoy y nyedyelimoy' [One and indivisible] Russia [underlined in red in the original]. The mood of the emigration underwent a certain revolution. It already agrees with the fact of existence of Polish Independence", Józef Piłsudski Institute of America in New York, Ukrainian Military Mission in Poland, 701/7/5, Information Communications of the Second Department of the General Staff and the Ministry of Internal Affairs. The attitude of the Soviet Government and Russian emigration to the ethnic issue in Russia, Report the Chief of the Second Department of the General Staff, Lieutenant Colonel Tadeusz Pełczyński of 28 July 1930, scan 717, p. 7 (on-line collection). Also the main press organs of the "white" emigration were subject to control, ibid., pp. 208-215 (on-line collection); ibid., scan 714, p. 4 (on-line collection). The Bolsheviks also inspired monarchist press, fuelling anti-Polish feelings: "In April this year, sensational news of the alleged agreement between the Polish Government and representatives of the Caucasian, Tatar, Ukrainian and Cossack independence organizations concerning the future territorial division of Russia appeared in the Russian monarchists' daily published in Belgrade under the title Tsarsky Vestnik (no. 89 of April 27 this year). On the basis of only the very entanglement of names of individual representatives we can infer that the news was also probably inspired by the Bolsheviks, all the more that it was immediately quoted in Soviet newspapers", ibid., Report of the Chief of the Second Department, Lieutenant Colonel Tadeusz Pełczyński of 28 July 1930, scan 716, p. 4 (on-line collection). Reports of the Ministry of Foreign Affairs and those of the Second Department of the General Staff concerned Russian emigrants in Germany, France, Finland, Hungary, Romania, Serbia, Austria, the Baltic States and Manchuria; Stanisławski, Myśl polityczna, p. 258.

60 Stanisławski, Myśl polityczna, pp. 202-203, fn. 223 and 226; R. Backer, Międzywojenny eurazjatyzm. Od intelektualnej kontrakulturacji do totalitaryzmu?, Łódź, 2000, pp. 208-209. At the 
The main person responsible for both the Promethean activity and contacts with the Russians on behalf of the Ministry of Foreign Affairs was the head of the Eastern Department, Tadeusz Hołówko (since 1927), ${ }^{61}$ and Tadeusz Schaetzel (since 1931).

In the early 1930s, Polish authorities carried out the consolidation of the Russian emigration and minority around the ruling camp. In 1931, the Interior Minister, Bronisław Pieracki, approved the statute of the following pro-state organizations: the Union of Russian Minority Organizations (URMO) ${ }^{62}$ and the emigration Russian Social Committee (RSC). ${ }^{63}$ The chief of the Eastern Department of the Ministry of Foreign Affairs, Tadeusz Hołówko, took part in the work on the formation of the RSC. He received from Filosofov a memorandum on the establishment of the Russian Social Committee. ${ }^{64}$ It was also with him, prior to submitting the letter, that Filosofov held confidential consultations, as indicated in the content of Sergey Kyelnich's letter, with regard to whom recruitment for co-operation was attempted: “Он [Filosofov] обещает етому Ком[ите]ту полную

present stage I have to omit the issue of co-operation of the Russians with Polish sovietological and academic centres, noting, however, that such co-operation existed, both in the case of the said Eastern Institute and the Scientific-Research Institute of Eastern Europe and the School of Political Sciences in Vilnius, where, in the academic year 1931/1932, more Russians (15) than representatives of all other minorities attended courses; M. Kornat, "Instytut Naukowo-Badawczy Europy Wschodniej w Wilnie (1930-1939) i jego wkład w rozwój polskiej sowietologii”, Kwartalnik Historyczny, 107 (2000), no. 3, p. 50.

${ }^{61}$ W. Materski, Na widecie. II Rzeczpospolita wobec Sowietów 1918-1943, Łódź, 2005, p. 329. Prior to assuming this position, Hołówko liaised between the Marshal and the nations of the former Russian Empire: "Over a few months [in 1925], he went on a whole series of confidential trips abroad, the aim of which was to renew contacts between Warsaw and the dispersed circles of anti-Soviet emigration. His interlocutors were representatives of Caucasian organizations and the Russians, however, the negotiations with the Ukrainians were of paramount importance", J.J. Bruski, Między prometeizmem a Realpolitik. II Rzeczpospolita wobec Ukrainy sowieckiej1921-1926, Kraków, 2010, p. 212.

6220 July 1931, Warsaw, "Pismo Ministra Spraw Wewnętrznych Bronisława Pierackiego do komisarza rządu m.st. Warszawy oraz wszystkich wojewodów z wyjątkiem śląskiego, pomorskiego, poznańskiego i kieleckiego, dotyczące Związku Rosyjskich Organizacji Mniejszościowych w Polsce", in: Polityka narodowościowa władz polskich wobec emigracji i mniejszości rosyjskiej w latach 1926-1935. Wybór dokumentów, ed. Ł. Dryblak, Przegląd Wschodni, 14 (2015), no. 1, pp. 228-229.

63 AAN, MSW, 82, Report on the life of national minorities for the second and third quarter of 1930., p. 75.

64 “Был составлен меморандум, объясняющий наши намерения. Философов передал его начальнику восточного отдела министерства иностранных дел Тадеушу Голувко [...] Русские эмигранты, с точки зрения международного нрава, были иностранцами, но Голувко признал, что существование их представительства будет полезно не только им, но и польской власти. Он убедил в этом министерство внутренних дел, утвердившее в 1931 году устав Российского Общественного Комитета в Польше. Его первым председателем стал Буланов, а одним из членов правления - Философов”, С.Л. Войцеховский, Эпизодь, Лондон-Канада, 1978 http://www.dk1868.ru/history/voytzexov.htm\#z151 (access: 14 January 2014). 
поддержку со стороны правительственных кругов, как материальную, так и политическую". ${ }^{65}$ As a correspondent of Segodnya, Kyelnich could prove to be a valuable collaborator, all the more that in addition to the establishment of the Committee, Filosofov also planned to "refresh" Za Svabodu! (Hołówko promised financial support). ${ }^{66}$ According to Kyelnich, it was an attempt to escape the political isolation in which he had got stuck, criticized or ignored by the majority of emigrants. Sergey Voytsiekhovsky, a correspondent for the newspapers Vozrozhdeniye and Segodnya, as well as a former resident of the Russian All-Military Union (ROVS), was an intermediary in the handing over of Filosofov's offer. Kyelnich did not agree to co-operate either in 1928 or in $1930 ;{ }^{67}$ in both cases, the funding was provided by Hołówko. ${ }^{68}$ Recruiting him would probably change the tone of the information he handed over to Mikhail Milrud's Riga daily for more favourable for Poland (over time, it might be transformed into closer co-operation). In order to strengthen his influence on the press market, in 1931 Filosofov attempted to urge the well-known Vilnius minority activist Boris Pimonov, the owner of Nashe Vremya (published with the supplement Segodnya) to combine his newspaper with Za Svabodu! ${ }^{69}$ According to Kyelnich, Filosofov affected the content of the material published in the Vilnius journal through its editor - “Оказывается, Марков там строго выполняет инструкции Фил<ософо>ва и ведет к обеденению с $3 a$ Свободу!" ${ }^{70}$ However, Kyelnich himself obtained this information from Georgy Shulgin, who, until 1931, was his confidant in the editorial team of Za Svabodu! ${ }^{71}$ Filosofov failed to establish co-operation either with Kyelnich, or with Pimonov. The reason was the differences of opinions and the reluctance of both of them to become politically subordinated to Filosofov. In addition to political factors, financial issues and matters of prestigious nature played a considerable role. It turned out that the fact of co-operation of both Filosofov and Pimonov with the Polish state did not guarantee understanding between them.

It is possible that, through Voytsiekhovsky, Filosofov also tried to seek rapprochement with the creators of the widely-read Paris daily Vozrozhdeniye. Perhaps, he also held conversations on this topic with the "right" liberal, professor Pyotr Struve, who, in 1931, was also the editor of the Eurasian magazine Rossiya $i$ Slavyanstvo. Thanks to his support, Filosofov could count on the strengthening

65 S. Kyelnich to M. Milrud, 17 December 1930, in: Л. Флейшман, Ю. Абызов, Б. Равдин, Русская печать в Риге: из истории газеть «Сегодня» 1930-х годов, vol. 1-5, Stanford 1997, vol. 1, p. 325.

66 Ibid., p. 326.

67 “Я сказал, что могбы пойти толко тогда, если бы Фил[ософов] согласился предоставить мне диктаторские права и право vето на его статьи, буде я признаю их врегньеми для дела", S. Kyelnich to M. Milrud, 17 December 1930, ibid., p. 326.

68 S. Kyelnich to M. Milrud, 12 December 1933, ibid., vol. 3, p. 160.

69 S. Kyelnich to M. Milrud, 17 December 1930, ibid., vol. 1, p. 327.

70 S. Kyelnich to M. Milrud, 18 December 1930, ibid., p. 330.

${ }^{71}$ S. Kyelnich to M. Milrud, 09 March 1931, ibid., vol. 3, pp. 169-170. 
of the pro-Polish orientation among emigrants. ${ }^{72}$ Struve's visit to Poland did not contribute to the revival of the press co-operation (except for a brief period at the turn of 1934 and 1935, when Struve wrote to Miecz [Sword]) ${ }^{73}$ it is for other reasons, however, that it is worth devoting more space here.

The professor first came to Poland on 22 June 1926, officially for the International Congress of Science, and unofficially - as suggested by Richard Pipes - in connection with the initiation by Piłsudski, in May of the same year, investigation into the "Trust" case. ${ }^{74}$ We know that, during the congress, they held a brief conversation which could not be of much importance due to the presence of third parties. ${ }^{75}$ Following his return to France, Struve published an article in which he welcomed the May coup, ${ }^{76}$ becoming part of his concept which assumed the good functioning of only old democracies; in other countries, "he tended to favour «strong men» exemplified by Marshal Piłsudski, who provided firm political leadership without depriving the citizenry of its basic civil rights, especially the right to own property". ${ }^{77}$

Struve's second visit took place at the turn of June and July of 1931. Officially, it was held in response to the invitation of the Russian Social Committee ${ }^{78}$ (allegedly, the initiator of Struve's invitation, who was then in the Balkans, was a member of the RSC, and also the correspondent of Vozrozhdeniye, and a sympathizer of the Eurasian movement, Sergey Voytsiekhovsky). ${ }^{79}$ Russian activists sent the invitation, probably following prior arrangements regarding this idea with Polish authorities, which agreeing to the arrival of one of the better-known, respected, Russian emigration professors, associated with the Eurasian movement, had the opportunity to make a gesture of good will towards the Russian community in Poland and Eurasian activists in the world, and to attempt to establish co-operation with the prominent Russian activist, known for his critical attitude to both Nazism and communism. ${ }^{80}$

Struve appeared in Poland at the All-Poland Congress of Russian Minority Organizations, and took part in an open meeting of a discussion group (Литера-

72 AAN, MSW, Ref. no. IV/85, Report on the life of national minorities for the second quarter of 1931, Warszawa, 1931, p. 64.

73 R. Pipes, Struve. Liberal on the Right, 1905-1944, London, 1980, p. 401.

74 "It is possible that Struve's trip to Poland was connected with Piłsudski's concern, and he might even have acted at Piłsudski's behest", Pipes, Struve, p. 386.

75 Ibid., p. 387.

76 П.Б. Струве, “Возвысшение Пилцудского”, Возрождение, 364 (1 July 1926), in: Дневник Политика (1925-1935), Москва-Париж, 2004, pp. 121-122.

77 Pipes, Struve, pp. 412, 414.

78 AAN, MSW, Ref. no. IV/85, Report on the life of national minorities for the second quarter of 1931 ..., pp. 63-64; Richard Pipes noted only among some dates in Struve's life that in June and July of 1931 he took trips to Warsaw, Berlin and Prague; Pipes, Struve, p. 465.

79 Сочинения русского периода, vol. 1: Стихотворения и поэмы, ed. Л. Флейшман, Москва, 2011, p. 107.

80 Pipes, Struve, p. 414. 
турное содружество), chaired by Filosofov. This group sympathized with members of the Novopokolentsy, and their communication platform was a supplement to Za Svabodu! - V svoyem uglu. According to Viktor Baidalakov, ${ }^{81}$ similar supplements were also published as part of the magazines Rossiya i Slavyanstvo, ed. P. Struve (Paris, 1928-1934), and Russkiy Golos, ed. V. Pronin (Belgrade, 19311941), popular with the members of the Novopokolentsy ${ }^{82}$ - it would be extremely interesting to examine the narratives of these two titles with regard to Poland, and the extent of interest in them by "Dwójka" ("The Second Department"). The professor also gave a series of hugely popular talks in Warsaw, Vilnius and Grodno on the inability to realize the Soviet five-year plan, and the Polish-Russian relations. His addresses could greatly assist in the campaign of winning round the Russians by the ruling camp; he said, among others, "that the idea of Polish independence has always been a necessary link in the system of political philosophy across the leading pre-revolutionary Russian intelligentsia, however, he added at the end: "I have not been appointed to speak on behalf of the whole Russian emigration about RussianPolish relations, but I must say that the national Russia which will come after the fall of the communist regime, will not have aggressive goals, but it will only deal with its internal affairs [...]". ${ }^{83}$ In his honour, Prof. Aleksander Lednicki held a breakfast party, which was attended by numerous scholars and the head of the Eastern Department of the Ministry of Foreign Affairs, Tadeusz Schaetzel. During Struve's stay, and following his departure from Poland, several articles maintained in a tone favourable for Poland were published in Vozrozhdeniye and Za Svabodu! ${ }^{84}$

As we already mentioned above, since 1928 Hołówko sought to set up a prostate, influential, illustrated Russian newspaper. ${ }^{85}$ Such an opportunity occurred

81 At the age of 18, V. Baidalakov (1900-1967) took part in the civil war on the side of the "whites", he evacuated to Yugoslavia together with Wrangel's armies, where he graduated in chemistry from the University of Belgrade, was an organizer of the National Alliance of the Russian Youth Abroad (NSRM), since 1931 the chairman of the National Alliance of the New Generation (NSNP), subsequently transformed into the National Alliance of Russian Solidarists (NTS).

82 Байдалаков, Да возвлечится Россия, р. 10.

83 AAN, MSW, Ref. no. IV/85, Report on the life of national minorities for the second quarter of 1931, pp. 63 and 64.

84 Д.В. Филосо́фов, “П.Б. Струве”, За Свободу!, 166 (26 June 1931); А.F., Доклад, “П.Б. Струве”, За Свободу!, 167 (27 June 1931); “П.Б. Струве в «Своем Углу»”, За Свободу!, 172 (3 July 1931); В. Клементьев, "В литературном содружестве. Беседа о втором и третьем поколении в емиграции. П.Б. Струве председателствовал на заседании”, За Свободу!, 175 (6 July 1931); П.Б. Струве, Письмо в редакцию За Свободу!, 178 (9 July 1931).

85 On the establishment of the RSC and Molva: “Возникновение этой коалиции предрешило судьбу газеты, основанной Савинковым, но ее замена новой, названной Молва, стала возможной не сразу. Нужно было договориться о программе, о редакции, сотрудниках и типографии. Подразумевалось само собой, что Философов останется издателем. Вероятно, не без помощи Голувки ему удалось получить согласие распространенной польской газеты «Экспресс Поранны» на использование ее великолепных, только что доставленных из Дрездена ротационных машин, позволивших украсить газетные листы новинкой - 
following the establishment of the Russian Social Committee - a coalition organization of Russian emigrants who decided to start a new daily, which could replace Za Svabodu! Before it happened, the supplement entitled Obiedinieniye, whose editorial board members sat on the board of the RSC, i.e. Vladimir Brandt, Nikolai Bulanov, Panteleimon Simansky, Dimitry Filosofov and Alexandr Khiriyakov, began to appear in Za Svabodu! The new daily appeared only about eight months after Hołówka's assassination, ${ }^{86}$ on 6 April 1932. In the same year, there was a division within the RSC; followed by leaving it by the activists associated with Filosofov, who quarrelled with Sergey Voytsiekhovsky, among others over the interpretation of Polish foreign policy, and specifically about the Polish-Soviet non-aggression pact. Voytsiekhovsky also attacked the minority Russian Youth Organization for the conciliatory attitude of its members to the USSR. The editorial staff of Molva stood up for the youth, while criticizing Voytsiekhovsky for his pro-Hitler attitude. ${ }^{87}$ His accusations lived to see the response of chairman Nikolai Shumlin, ${ }^{88}$ whose views resulted not from his sympathies for the Soviet Union, but from his loyalist attitude towards the Polish state. ${ }^{89}$

The Polish authorities used their influence in the widely read Russian papers not only to combat communist agitation, but also to inspire the Russian-speaking public opinion, also abroad. ${ }^{90}$

цветными иллюстрациями", С.Л. Войцеховский, Эпизоды, http://www.dk1868.ru/history/ voytzexov.htm\#z151 (access: 14 January 2014).

86 The Russian press very strongly condemned Hołówka's assassination: "Rosjanie”, Sprawy Narodowościowe, nos. 4-5 (1931), p. 478; Filosofov devoted to him a long obituary, outlining his profile and activity: “Для покойнаго 'Пана Тадеуша' - в особенности, Польша мыслилась не как государство чисто этнографическое. Для Голувки, первыя строфы 'Пана Тадеуша' - ‘Литва отчизна моя...' были самой жисой реальностью, отнюдь не художественным образом. [...] Но сделавшись слугою государства, он не сделался чиновником. И в этом была его сила, его обаятельность. План грандиознаво храма 'братцтва народов’ был у него всегда перед глазами. [...] Если бы я составлял проект этого памятника, я бы сделал его очень простым. Высокая, поставленная стоймя, каменная плита, а на ней надпись: 'Борцу за братство народов””, Д.В. Филосо́фов, “Памяти 'Пана Тадеуша”, За Свободу!, 236 (10 June 1931).

87 W. Skrunda, "Rosyjska 'Mniejszościowa' Organizacja Młodzieżowa w Polsce międzywojennej (ROM). Okoliczności powstania”, Studia Rossica, 5 (1997), p. 171.

${ }^{88}$ According to the materials of the Military Police (WSW), N. Shumlin (RYO's chairman) was an agent of the Second Department and, at the same time, of German military intelligence, AIPN BU, 2386/16886, the Leadership of WSW [the Military Police]1960-1963, Information concerning the origins and activity of the organization National Alliance of Russian Solidarists. NTS, Warsaw, October 1961. fol. 67.

89 "We strive - said Shumlin - to create from the local Russian population a perfect minority, one that is conscious of their cultural distinctiveness, but at the same time eagerly supporting all efforts of the majority to strengthen the power of the Polish state", quoted after: Skrunda, Rosyjska 'Mniejszościowa' Organizacja Młodzieżowa, p. 168.

90 Cf. Ł. Dryblak, "Inspiracja i formy współpracy polskich instytucji państwowych z wydawcami i redakcjami pism rosyjskich w latach 1919-1935 - zarys problematyki", Dzieje Najnowsze, 48 (2016), no. 1, pp. 33-52. 
At the same time it should be emphasized that, despite the opinion of his Russian political opponents, Filosofov collaborated with the Poles for ideological, and not financial reasons, as typical agents. Despite the financial dependence upon the Polish state, he maintained the independence of his views, did not always agree with the ethnic and religious policy implemented by Piłsudski's subordinates ${ }^{91}$ and, in principle, actually lamented the lack of it - "There are two «camps» in Poland. Some say: there are the Ukrainians, Belarusians, but there are no Russians. We are ready to do much for the Ukrainians and Belarusians. Yet, nothing is being done. Others say: there are only the Russians. But nothing is being done for them". ${ }^{92}$ Filosofov was the most persistent knight of the "third" Russia - anti-imperial, anti-Bolshevik, democratic, respecting the rights of minorities, which is why in his work he focused on improving Polish-Russian relations, and fought all manifestations of chauvinism both among the Russians, and other nationalities..$^{93}$ Commenting upon the political situation, he tried to remain objective, calling for the mitigation of ethnic conflicts between the Poles, Ukrainians and Russians, which - in his opinion - could only benefit the Bolsheviks.

It seems that for the Polish authorities the year 1931 was a turning point in terms of gaining influence among both the Russian minority and emigration, among which the RSC - established thanks to Filosofov - as a coalition organization gained a lot of support from the Russians. ${ }^{94}$

\section{The NTS - its establishment and cooperation with Division "East"}

The alliance that turned into the NTS was formed from the merger of Russian youth organizations from Bulgaria and Yugoslavia into the NSRM (Национальный Союз Русской Молодежи за Рубежом [The National Alliance of the Russian Youth Abroad]). ${ }^{95}$ The First Congress of the Alliance was held in 1930, during which other youth organizations joined. The Second Congress, which was attended by representatives from seven countries, including Poland represented by Alexandr Würgler, took place the following year (the identification sign of the delegates getting off the train onto the platform was the Eurasian newspaper Rossiya $i$ Slavyanstvo). ${ }^{96}$

91 Examples of articles critical in tone: Д.В. Филосо́фов, “Ядовитые цветы”, За Свободу!, 187 (17 August 1926); "Русификация”, За Свободу!, 217 (20 September 1926).

92 "Listy Dymitrija Fiłosofowa do Mariana Zdziechowsiego", ed. P. Ławriniec, Zeszyty Historyczne, 68 (2008), pp. 185-186.

93 Д.В. Филосо́фов, “Единый православный фронт”, За Свободу!, 264 (07 December 1928).

94 AAN, MSW, Ref. no. IV/86, Report on the life of national minorities for the second quarter of 1931, Warszawa, 1931, p. 50.

95 А.В. Окороков, Русская эмиграция, Москва, 2003, р. 47.

96 А. Вюрглер, “На ІІ-ом съезде Нац. Союза Нового Поколения (б. НСРМ)”, За Свободу!, 4 (6 January 1932), p. 6. Alexandr Würgler (1901-1943), left for Switzerland in 1920 (he was 
It was one of the most important congresses. It adopted the new name of the organization (Национальный Союз Нового Поколения [the National Alliance of the New Generation]) and its programme; it also elected its authorities - Viktor Baidalakov was appointed the chairman of the board in Belgrade, and the chairman of the board based in Paris - Prince Sergey Nikolayevich Leykhtenbergskiy; it was also established that a member can only be a person born after $1895^{97}$ older members had to obtain permission of the Executive Bureau. It was in this way that they wanted to avoid disputes within the party, which the older politicized generation was so permeated with. ${ }^{98}$

It is difficult to determine when the first contacts of Polish immigrants with the youth organizations in the Balkans took place; hypothetically, the Congress of Russian Writers in Belgrade in 1928, which was attended by representatives of the Union of Russian Writers and Journalists in Poland - with the chairman, Sergey Kyelnich, and Anatol Wielmin (although rather neither of them became a member of the NTS) provided an opportunity to do so. ${ }^{99}$ Alexandr Würgler joined the union probably in the same year; he may have already been linked up with the New Generation movement at that time. He may have come with the task to recruit new sympathizers for them. Acting in the Union of Russian Writers and Journalists (Союз русских писателей и журналистов в Польше), he must have come into contact with Filosofov. The main elements that could enable the establishment of co-operation between them included anti-bolshevism, anti-totalitarianism, respect for other nationalities, federationalism, to some extent democracy, and activation of young people. Although we do not know when Division "East" came in contact with the New Generation movement, and whether Filosofov's meeting with Würgler was held under its patronage, or whether Filosofov put Würgler in touch with the Second Department, it is certain that it must have been done with the knowledge and consent of "Dwójka's" [the Second Department's] leadership.

a Swiss citizen), in 1923 he began studying at the Russian Institute of Economics, in 1928 he obtained the title of a Doctor of Economics, then he went to Poland and joined the Union of Russian Writers and Journalists; in 1931 he was a delegate to the Congress of the NSRM; in 1934 he participated in the Third Congress and became a member of the Executive Bureau; he was the head of the Polish branch of the NTS, and collaborated with Japanese intelligence through the Japanese attaché, General Savada, and the chief of Division "East" of the Second Department of the General Staff, Captain Jerzy Niezbrzycki; during the World War he undertook collaboration with a general at Sonderdivision "R", Boris Smyslovsky, an Abwehr officer; thanks to the co-operation with Sergey Voytsiekhovsky, the chairman of the Russian Committee in Warsaw, he carried out the illegal transfer members of the NTS to the German-occupied areas of Russia; it was probably one of the reasons (in addition to contacts with the Polish underground) for his assassination by a Gestapo agent in 1943 (the NKGB [People's Commissariat for State Security] also had their share in this murder); И.В. Грибков, Д.А. Жуков, И.И. Ковтун, Особый штаб “Россия", Москва, 2011, pp. 81, 84, 92, 100; Байдалаков, Да возвлечится Россия, р. 83.

97 Вюрглер, На ІІ ом съезде, р. 6.

98 Ibid.

99 AAN, MSW, Ref. no. 1932, fol. 41-46. 
As already mentioned, the New Generation were a youth movement, and it was young people that Filosofov backed in his work. One of the major problems of the Russian diaspora was the ageing of its members; young Russians were becoming less and less sensitive to the problems of emigration, or interested in the situation in the Soviet Union, and even underwent assimilation, which affected especially those Russians who entered into nationally (ethnically) mixed marriages, and were awarded the Polish citizenship. These problems were the subject of Filosofov's concern and he counteracted them not through anti-Polish propaganda, as some far-right Russian circles in the Borderlands did, but by holding the Polish Great Emigration as a model for the Russian emigration ${ }^{100}$ - "Сколько надо сознательности, мужества и сил, чтобы бороться с коммунизмом и с шовинизмом, и в этой борьбе не забывать о ежедневной работе в 'огороде'. Русской эмигр<антской> молодежи (и там, в России!) надо заражаться психологией Мицкевичей [...]". ${ }^{101}$ In order to activate young people, he provided them in November 1927 with some space on the pages of Za Svabodu!, publishing the supplement Yedinyenye which was to become a platform for the exchange of views of the Russian youth. ${ }^{102}$ In January 1930, along with Za Svabodu! came another supplement for the youth - V svoyem uglu; and the composition of its editorial board included Vladimir Brandt, ${ }^{103}$ Antoni Dąbrowski, ${ }^{104}$ Vasily Klemientiev, ${ }^{105}$

100 A. Nowak, Dymitr Fiłosofow: dyskusja z polska "mickiewiczologia" czy z polskim kompleksem?, in: Akademie nauk, uniwersytety, organizacje nauki, polsko-rosyjskie relacje $w$ sferze nauki XVIII$X X$ w., ed. L. Zasztowt, Warszawa, 2013, p. 344.

101 D. Filosofov to St. and J. Stempowski, 14 July 1930, Warsaw (the original in the Library of the University of Warsaw), “От эстетики к этике. Из переписки Д.В. Философова. 1920-1932”, Наме Наследие, 63-64 (2002), http://www.nasledie-Rus'.ru/podshivka/6407.php (access: 9 April 2015).

102 “От редакционной коллегии”, За Свободу!, 273 (27 November 1927).

103 W.W. Brandt (1892-1942), Lieutenant-Colonel of the Volunteer Army, an associate of the Second Department of the General Staff, member of the People's Union for the Defence of Homeland and Freedom, the Brotherhood of Russian Truth, the "Tavern of Poets", the literary group "Literaturnoye Sodruzhestvo", collaborator of Za Svabodu!, member of the editorial committee of Molva; following Filisofov's departure, a co-editor-in-chief of Meu (Sword) - an unofficial organ of the NTS, organizer of the secret "school" for NTS activists near Warsaw; Грибков, Жуков, Ковтун, Особый штаб “Россия”, р. 90; Т.Д. Исмагулова, “Русская эмиграция в Польше (Владимир Бранд - поэт и воин 'русской Варшавы')”, in: Зарубежная Россия 1917-1939 z2., ed. В.Ю. Черняев, Санкт-Петербург, 2003, pp. 347-350; Ulatowski, Niezbrzycki. Wybrane aspekty biografi i wywiadowczej kierownika Referatu „Wschód”, https://www.academia. edu/3459067/\%C5\%81ukasz_Ulatowski_Niezbrzycki_wybrane_aspekty_biografi i_wywia dowczej_kierownika_Referatu_Wsch\%C3\%B3d_(access: 23 April 2015), p. 26.

104 A.S. Dąbrowski (1889-1938), born in Voronezh province [guberniya], died in Warsaw, a former officer, participant in World War I, member of the "Literaturnoye Sodruzhestvo", collaborator of numerous newspapers, including Za Svabodu!, http://www.mochola.org/russiaabroad/ruspldb/ ruspl_c.htm (access: 11 April 2015).

105 W.F. Klemientiew, a prose writer, member of the "Literaturnoye Sodruzhestvo", columnist of the following newspapers: Za Svabodu!, Molva and Meu (Sword). 
and Nikolai Riazancev, ${ }^{106}$ who eventually emerged as sympathizers of the NSRM. Written by its representative in Poland, Alexandr Würgler, the first issue of the supplement appeared on 30 April 1931, extensively informing about the activities of the NSRM. ${ }^{107}$

At the turn of 1931 and 1932, the $2^{\text {nd }}$ Congress of the NSRM was held in Belgrade. The Polish branch was represented by Würgler, who reported on its course in "V svoyem uglu", and informed on the foundation of a new union under the name of the National Alliance of the New Generation. ${ }^{108}$ Writing about the tasks of the Alliance, he singled out as the major ones the need to create "Vielikaya Rossiya"; with a view to achieving this, he considered it necessary to spark off a national revolution and establish a dictatorship for the transitional period. He also called for the unification of all anti-communist organizations, fighting against the theory of evolution of the Bolshevik system, preventing the deprivation of the Russians of their national identity with the help of social and cultural organizations, and the preparation of the revolutionary cadre. He finished the article with an announcement addressed to those interested in the movement in which he encouraged them to report to the editorial team of $V$ svoyem uglu. The ideological foundations of the NSNP were published in the same issue, and included: 1 . the establishment of a strong, central, trans-class and trans-party authority; 2 . the enactment of civil liberties, equality before the law, the abolition of class and estate privileges; 3. "In internal policy, the maintenance of healthy national egoism [...]", in foreign policy, striving for possibly close cultural and political co-operation with the Slavs; 4. "The recognition of the right to national self-determination for the nations forming Russia"; 5 . the solution of the agrarian issue; 6 . the introduction of economic freedom, restricted only in the interest of the state. ${ }^{109}$ In characterizing the views of members of the New Generation movement, we should refer to the London lectures of Wiktor Sukiennicki, a legal theorist, sovietologist and expert on the subject of Russia, who described them as democrats, supporters of the federal system, but not the dismemberment of Russia. ${ }^{110}$

The Polish branch of the NSNP had numerous local offices (most of them in the Borderlands), ${ }^{111}$ counting in the mid-1930s - according to General Secretary

106 N.A. Riazancev (1907-?) born in Kovel, a member of the group "V svoyem uglu" and the editorial board of the supplement of the same name, member of the "Literaturnoye Sodruzhestvo"; in the early 1930s, he moved to France; he studied chemistry, participated in the meetings of the "Green Lamp", http://www.dommuseum.ru/index.php?mdist=\&pid=12492\&PHPSESSID=da6e293f80df7744931d451004f6ae4b (access: 11 April 2015).

107 А. Вюрглер, “Н.С.Р.М.”, За Свободу!, 114 (30 April 1931).

108 Id., "На II-ом съезде...", За Свободу!, 4 (06 January 1932).

109 Ibid.

110 W. Sukiennicki, Trzydzieści lat emigracji rosyjskiej, London, 1950, p. 14.

111 “До 1939 года Польский отдел был одним из наиболее крупных Отделов НТС”, Я. Трушнович, “К истории Нородно-Трудового Союза”, Посев, 7 (2000), http://www.posev. 
Mikhail Gieorgiyevski - about 150 members, ${ }^{112}$ which placed the Polish branch in the third place in Europe. ${ }^{113}$ According to Stanisławski, its members recruited not only emigrants, but also members of the minority ROM, Ukrainians, Cossacks and others, establishing on the territory of the Republic of Poland 14 branches, ${ }^{114}$ including in Warsaw, Łódź, Vilnius, Lvov, Sosnowiec, Kalisz, Brest-on-the-Bug. ${ }^{115}$ It is possible that the ROM, the influence of which was also extended over the Russian Students Union and the Orthodox seminaries in Warsaw and Krzemieniec, as well as the universities and secondary schools (including Wawelberg's School) in which the Russians studied, was a cover for the NSNP. ${ }^{116}$ New members were recruited through the press, ${ }^{117}$ meetings and lectures (in the Borderlands, it had to be done with the consent of state authorities, as the Russians not residing in the eastern provinces had to have special permission to move around their area - see the case of Vladimir Brandt ${ }^{118}$ ), and in the same way the denationalization of the Russian youth was counteracted. In all the relationships of NTS activists, whom we were able to reach, the assessment of the activity of the Polish section was very good; also its perfect concealment and good co-operation with the Poles were emphasized. ${ }^{119}$ The scale of the NSNP's/NTS's activity is surprising for three reasons, and deserves special attention. Firstly, tolerating the recruitment of non-Russians must have been at odds with the activity of Agency no. 2 of the Second Department of the General Staff; secondly, territorial administration generally looked unfavourably at the initiatives undertaken jointly by the Russian minority and émigré community, because it delayed the assimilation of the Russians; thirdly, the activity of the NTS in the eastern provinces required special permits

ru/files/nts-about/ne7006.htm (access: 9 April 2015). Y. Trushnovich, a son Alexander (18931954), the well-known NTS activist, who was murdered by the KGB; with his father and mother left the USSR for Yugoslavia, with the help of the Polish Embassy, and settled in West Germany after the war; an NTS activist, journalist and editor of Posiew.

112 Из протоколов допросов лидера Начионально-Трудового Союза Нового Поколения М.А. Георгиевского іп: Политическая история русской эмиграчии 1920-1940 гг. Документь и материаль, ed. А.Ф. Киселев, Москва, 1999: http://www.russky.com/history/library/emigration/emigration3.htm\#290 (access: 27 April 2015).

113 Stanisławski, Myśl polityczna, p. 201.

114 Ibid., p. 202, fn. 222.

115 AIPN BU, 2386/16886, Information, fol. 68; Байдалаков, Да возвлечится Россия, p. 18.

116 AIPN BU, 2386/16886, Information, fol. 68.

117 The subject of the youth, as already mentioned, was often brought up by Filosofov, but also by his younger colleagues from $V$ svoyem uglu, А. Домбровский, “Молот и стекло”, За Свободу!, 265 (05 October 1931); В. Брандт, “Чёрная работа", За Свободу!, 230 (31 August 1931); И. Метелица, “Борьба с денационализацей”, За Свободу!, 298 (10 November 1931).

118 Исмагулова, Русская эмиграция, р. 350.

119 Б. Прянишников, Новопоколенцы, Мэриленд, 1986, p. 98; Е. Дивнич, NTS, Нам пора объясниться!, Нью-Йорк, 1968, p. 36; "I knew that the section of the NTS in Poland was large and well organized. But I had no idea that the atmosphere of such secrecy and concealment prevailed in it", A. Stolypin, Cesarstwo i wygnanie, transl. by P. Hertz, Warszawa, 1998, pp. 209, 199-200. 
from province administrators (emigrants could not move around them freely) and the overcoming of their reluctance; also their tolerance for the activities of Russian organizations decreased year by year (such an attitude was presented especially by the administrator of the Polesie province, Waclaw Kostka-Biernacki and the administrator of the Volyn province, Henryk Józewski).

After the closing of Za Svabodu!, activists of the New Generation movement published in Molva, whose publisher was Vladimir Brandt, and the editor-inchief, Nikolai Riazancev. In May 1934, Molva was replaced by the weekly Miecz (Sword), run by the editorial committee composed of Filosofov (the chairman), Leon Gomolicki (the secretary), Yevgeniya Weber-Khiryakova and Georgy Sokolov (members), and Antoni Dąbrowski (the publisher and editor-in-chief). It was Filosofov's international project, parallel to which the Parisian edition of Miecz (Sword), edited by Merezhkovsky, was issued. It contained contributions by famous Russian intellectuals, e.g. from Poland and France (Gippius and Merezhkovsky), and Czechoslovakia (Alfred Bem). As a result of disagreements between Merezhkovsky and Filosofov, this co-operation was broken off in September $1934 .{ }^{120} \#$ In his last article, Filosofov announced the transfer of the weekly to the younger generation, with Brandt and Sokolov becoming the new editors. As a result of the failure of the idea of Meu (Sword) as a weekly unifying Russian writers across Europe, Filosofov turned to Polish intellectuals. In November 1934, the first meeting of the discussion group "Domik v Kolomne", chaired by him as a "starshina", was held. ${ }^{121}$ The meetings were typically Russian-Polish in nature (with the Poles prevailing among the guests), but sometimes representatives of other nationalities, such as the Ukrainians, also attended. At the beginning of 1936, the "starshina's" health condition worsened, in April he underwent a treatment in Otwock, where he died on 5 August 1940 in "Wiktorówka", under the care of Dr. Zofia Dobrowolska. ${ }^{122}$

The articles appearing in Молв $\mathrm{a}$ and Меч (Sword) had two edges: anti-German and anti-Soviet ${ }^{123}$ (generally anti-totalitarian ${ }^{124}$ ); their authors sought a third way, which would allow them to regain their homeland, they sought support from other countries. ${ }^{125}$ They were of the opinion that any aggression against the USSR, also

120 Д.В. Филосо́фов, “К. Читателям”, Меч, 19-20 (23 September 1934), pp. 3-4.

121 P. Mitzner, Warszawski “Domek w Kołomnie”, Warszawa, 2014, p. 64.

122 Ibid., p. 91.

123 Д.В. Филосо́фов, “Восточноевропэйская конвенция”, Молва, 153 (08 July 1933); “Мы должны сказать себе раз на всегда, что сов. правительство не может эволюционировать”, В. Брандт, "Тактический ход, Меч, 8 (24 June 1934), pp. 8-9; An editorial by the new editorial team, Меч, 21 (07 October 1934), p. 1.

124 Д.В. Филосо́фов, “Десять лет фашизма”, Молва, 172 (29 October 1932).

125 “Эмиграция считает возможным 'третий путь', видя в Японии естецственнаго союзника Национальной России и считать, что жизненные интересы Японии требуют сознания Национальной России и союза с Ней. Совершенно верно говорит 'Знамия России'. [...] Благодетельным для обоих империй является лишь третий путь”, В. Брандт, Национальная Россия и Япония, Меч, 42 (24 October 1935), p. 4. 
by the the Japanese, should obtain support from the emigration; their opinion was shared by the majority of the Russian émigrés in Warsaw, in contrast to the very few Warsaw supporters of Milukov's group, who considered such conduct as betrayal. ${ }^{126}$ They combated the Soviet-inspired Alexander Kazem-Bek's "Smienoviekhovs" and "Mladorossis" movements deriving from the Eurasian ideology, ${ }^{127}$ the fascists from the Russian People's Liberation Movement (Российское Освободительное Национальное Движение), founded in Germany in April 1933, ${ }^{128}$ and the leader of the Cossacks in the Far East, Ataman Grigory Semyonov. ${ }^{129}$

In their articles, they did not comment on the policy of the Polish government, nor did they engage in the affairs of the minorities, although their calls were directed to all the Russians, in particular to the youth. They repeatedly manifested their loyalty to the Polish state, publishing a lot of information and numerous photos from state ceremonies and holidays, especially those feting Marshal Józef Piłsudski. ${ }^{130}$ It should be noted that in their activity emigrants, perhaps not quite consciously, often imitated the ruling camps in the countries where they lived. It certainly happened that their actions were inspired by the hosts of a given country. Also in Poland we can see a certain fascination with Piłsudski's camp, which was reflected in the idea of creating the "Order of the Poor Knights" (Орден Бедных $P$ sı, apeü) (repeatedly cited by Filosofov; he used this term with reference to the group of "V svoyem uglu"), ${ }^{131}$ a concept of the transitional dictatorship by Würgler, or the article on the occasion of Piłsudski's name day - "Мы эмигранты с особой ясностью осознаем, какое значение имеет вождь". ${ }^{132}$ Certainly, it is not known to what extent it was caused by the functioning of the Polish environment, and

126 AAN, MSW, Ref. no. IV/88, Report on the life of national minorities for the first quarter of 1932, Warszawa, 1932, p. 53.

127 Д.В. Филосо́фов, “Где бюро меньшинств”, Молва, 84 (11 April 1933); Байдалаков, Да возвлечится Россия, р. 8.

128 “'РОНД’ и т.п. организации - явление печальное и даже позорное. Но еще печальнее и еще позорнее, забывать свои основной долг по отношению к родине [...]”, А. Вюрглер, “О задачах эмиграции”, Молва, 123 (31 Мау 1933).

129 Брандт, Национальная Россия, р. 4.

130 A lot of space was devoted to the Marshal's death - "И мы русские эмигранты в Польше, навсегда сохраним благодарную память о той огненной ненависти с которою Он относился ко всему тому, подлому и лицемерному - ко всему тому, что заставило нас покинуть нашу родину и принять протянутую руку братского полскаго народа Кончина Маршала", Меч, 53 (19 May 1935), p. 1.

131 “Моему сердцу всего ближе группа Своего угла, и я тихо радуюсь, что именно она одухотворяет новую газету. Пользуюсь последней возможностью указать этой группе «бедных рыцарей» свою искреннюю признательность за ту неустанную моральную поддержку которую она оказывала прекращающейся ныне газете”, Д.В. Филосо́фов, “Прощальная станция”, За Свободу!, 75 (3 April 1932), p. 2; id., “От чего зависит возрождение эмиграции? Доклад, прочитанный 18 марта 1934 г. на собрании Литературного Содружества", Меч, 5 (3 June 1934), p. 9.

132 “Непоколебимый”, Меч, 44 (19 March 1935), p. 1. 
to what extent by the pan-European trend continuing especially among young people - "Differing just like their 'fathers' in often significant details, the 'young' unanimously pined for a 'brilliant leader' who would be able to gather and organize all active forces, national 'living forces', and overthrow materialistic, godless, internationalist Bolshevism, as well as rebuild a powerful and magnificent edifice of the 'Russian' ('one hundred-nation' and 'one hundred-language', and not just 'Great Russian') Empire”. ${ }^{133}$

\section{The road to war}

Looking beyond the chronological frame of the article, we should assert that the Polish-Russian relations in the second half of the 1930s are still waiting for a thorough examination. It is now known that this was a period of intensification of co-operation between the NTS and the Second Department of the General Staff. Among the involved officers, an important role was probably played by the chief of Division "East", mentioned in many Russian memoirs, Captain Jerzy Niezbrzycki. ${ }^{134}$ The longest description of a meeting with Niezbrzycki was included in Brzhestovskiy's account, where he wrote, among other things: "Раз к нам в класс пришёл началник школы - шеф 'реферат всхуд' и, кажется, инициатор сотрудничества с НТС, по фамилии, на сколко сейчас помню, Врага. Поздоровавшись с нами, сказал, как он рад, что традиционное русское сопротивление силе зла продолжается, что теперь представителей етого сопротивления он видит в НТС и в нас и что-то ещё в етом духе". ${ }^{135}$ This is in conflict with the findings of Łukasz Ulatowski, who said that Niezbrzycki very reluctantly used "the intelligence services of only the white Russians. He totally rejected the idea of beginning deeper co-operation with the emigration. [...] The contacts of Division "East" with emigrants, individuals, flickered only throughout the 1930s". 136 The author admits that a small number of "the whites" worked for

133 Sukiennicki, Trzydzieści lat, p. 10. Among other minorities, Piłsudski enjoyed a particular cult among the members of the youth Zionist Jewish organization "Betar", like the NTS benefiting from the support from the state.

134 Captain J. Niezbrzycki, in the years 1932-1939 the chief of Division “East”, in September 1939 delegated by the Chief of Staff of the Commander-in-Chief "to hold talks with Romanian intelligence, from which he obtained permission for the activities of the Polish intelligence to be tolerated (Agency "R"). Himself stigmatized as a collaborator of the Sanation movement, he was not entrusted with a function in the Second Department of the General Staff of the Commander-in-Chief, Załącznik do sprawozdania $z$ działalności Oddziału II Sztabu Głównego, compiled by T. Dubicki and A. Suchcitz, in: Wywiad i kontrwywiad wojskowy II RP, vol. 1, ed. T. Dubicki, Łomianki, 2010, p. 385, fn. 144.

135 М. Бржестовский, “Свидание с родиной”, in: От зарубежья до Москвы. Нароно-Трудовой Союз (НТС) в воспоминаниях и документах 1924-2014, еd. В. Сендеров, Москва, 2014, p. 95.

136 Ł. Ulatowski, Niezbrzycki. Wybrane aspekty biografii wywiadowczej kierownika Referatu “Wschód”, p. 26, https://www.academia.edu/3459067/\%C5\%81ukasz_Ulatowski_Niezbrzycki_ 
the Second Department, but adds that because of the lack of available documents and accounts, this issue "has not been duly clarified yet". ${ }^{137}$ Most of the documents of the Second Department, stored in the Russian State Military Archive, is indeed difficult to access; in this case, however, it is all the more worth reaching for the available Russian accounts, and those of the Russian émigré press. ${ }^{138}$

Another person coordinating co-operation with the Russians was Henryk Suchenek-Suchocki. Although in the 1930s he was no longer an employee of the Second Department, he could still keep in contact with it and somehow co-ordinate, on its behalf, the activities aimed at the Russians as part of the Department of Ethnic Minorities of the Ministry of the Interior, of which he was the head. ${ }^{139}$

The beginnings of the activity of the New Generation movement in Poland date back to the turn of the 1920s and 1930s, but the first talks between the Second Department and the representative of the Executive Bureau of the NTS, Mikhail Gieorgiyevski, confirmed in the sources, took place only in the second half of the 1930s. ${ }^{140}$ The co-operation of the NSRM/NTS with the Second Department was launched not in 1937 through the Japanese intelligence, as Gribkov, Zhukov and Kovtun claim in their work, but - as we have shown - in the early 1930s, without the Japanese agency. ${ }^{141}$ Among the activists of the New Generation move-

wybrane_aspekty_biografii_wywiadowczej_kierownika_Referatu_Wsch\%C3\%B3d_(access: 23 April 2015).

137 Ibid.

138 So far, the author has managed to identify ten Russian accounts containing information about the activities of the NTS in Poland by: Yevgeny Divnich, Viktor Baidalakov, Mikhail Brzhestovskiy, Mikhail Gieorgiyevski, Alexander Kolkov, Georgi Okolovich, Boris Pryanishnikov, Arkady Stolypin, Yaroslav Trushnovich and Sergei Voytsiekhovsky.

139 AIPN BU, 2386/16886, Information, fol. 68.

140 "He told me [Gieorgiyevski] that the NTS had the support of the Polish government. With the help of the Poles in and around Vilnius, the window through which our people penetrated into the Soviet Union, was opened”, Stolypin, Cesarstwo i wygnanie, pp. 199-200; “Он тогда [the end of 1938] обьезжал отделы Союза в разных странах и из Варшавы приехал в Берлин”, "Генералный секретар ИБ проф. М.А. Георгиевский договорился с Польяками о совместной работе на советско-полской границе”, Прянишников, Новопоколенцы, р. 90; “Георгиевский поддерживал связь с рядом иностранных разведок, в частности с японской и польской разведками, которые финансировали НТСНП, снабжали оружием, фиктивными документами и организовывали переброску агентов для проведения шпионской и террористической деятельности. По этой шпионской и подрывной работе Георгиевский был тесно связан с японскими военными атташе в Варшаве и в Берлине генералами Савада и Кавабэ и начальником восточного отдела Польского Генерального Штаба Незбражицким. [...] В 1937 г. в СССР были переброшены с террористическими заданиями два члена НТС Околович Г.С. и Колков А.Г.”, “Приговор Военной Коллегии Верховного Суда Союза ССР”, in: Политическая история, http://www.russky.com/history/library/emigration/ emigration3.htm \# 290 (access: 27 April 2015); see fn. 108.

${ }^{141}$ Грибков, Жуков, Ковтун, Особый штаб „Россия”, р. 89. These authors do not refer to the earlier activity of the New Generation movement in Poland. 
ment involved in co-operation with the Poles, the most important figures on the Russian side were the head of the Polish branch of the NTS, Alexandr Würgler, member of the Executive Bureau of the NTS, Vladimir Brandt, chairman of the ROM, Nikolai Shumlin, and member of the NTS leadership, Georgy Okolovich, supervising the transfer of activists to the USSR. The issue of the school for NTS members, organized with the support of the Second Department, and the staff functioning at it, whose chief was Okolovich (“штаб похода НСНП”), is still unclear. ${ }^{142}$ It is difficult to pinpoint where it could be located, and whether it served only to train NTS members (members of the organization from all over Europe were trained in it). So far, we have managed to reach only one more detailed report which describes the course of such training. Mikhail Brzhestovskiy came to Poland from Germany in the summer of 1939 at Viktor Baidalakov's request, in order to follow such a course; after its completion, he was to be transferred to the USSR. The course lasted two months (June-July), during which time the participants were taught, among others, appropriate behaviour, the topography of the border regions, the geography of Russia, its railway network, encryption of correspondence, photography, the structure of the party and state apparatus, opening locks, using hand guns, Soviet terminology and everyday life (the materials that Okolovich created after his return from his first mission to the USSR in 1938 were used), 60-70-kilometre keep-fit marches were also organized. ${ }^{143}$ Apart from the officers of the Second Department, the courses were taught by Gieorgy Okolovich, Shura Kolkov, Kornet Alexandr Chuprunov and, as should be assumed, Vladimir Brandt. Polish intelligence also facilitated the transfer of NTS members to the USSR, and fabricated documents for them. ${ }^{144}$ It is interesting that it was through Stolypin, who completed a mission to Poland in the summer of 1939, that the NTS headquarters tried to warn the Poles about the attack from the east: "When I explained the purpose of my trip (warning the Poles about the danger threatening them from the Soviet side), he [Würgler] told me earnestly that I would not achieve anything. Having faithful friends in the Polish General Staff (such as Colonel Wraga, the chief of the Russian division, whom I subsequently met), he was already trying to open their eyes" ${ }^{145}$ Assuming that the Russians

${ }^{142}$ Первое приложение [a report from A. Kolkov's trip to the USSR], in: А.П. Столыпин, На службе России. Очерки по истории НТС, 1986, http://ntsrs.ru/content/prilozheniya-ktretey-glave (access: 27 April 2015). According to Okolovich's account, which is referred to by both Pryanishnikov and Stolypin, in 1938 six trained activists of the Yugoslav branch of the NTS were sent from the Polish territory (three of them were killed, one failed to penetrate the border, only two - G. Okolovich and A. Kolkov - took a few months' trip around the USSR); the next three groups were sent in August 1939; Прянишников, Новопоколенцы, pp. 100-101; М. Бржестовский, Свидание с родиной, р. 95.

143 Ibid., pp. 92-93.

144 Дивнич, НTC, p. 36.

145 Stolypin, Cesarstwo i wygnanie, p. 209. 
actually presented evidence of the aggressive intentions of the USSR with regard to Poland, it is doubtful that Niezbrzycki underestimated them. ${ }^{146}$ It seems that the information was blocked or misinterpreted at a higher level. Finding out about the attitude of the deputy director of the Political and Economic Department of the Ministry of Foreign Affairs and the head of the Eastern Department at the Ministry of Foreign Affairs, Tadeusz Kobylanski (according to Pawel Wieczorkiewicz, referring to Russian monographs, a Razviedupr agent since 1937$)^{147}$ to the NTS activity, could play an important role in explaining the issue. His critical assessment of the activities of this organization could indicate that it was him who "blocked" the information, and it would corroborate the thesis of his secretive relations with the Soviets.

Polish-Russian co-operation was to continue also in Romania, among others through Georgi Okolovich, Mikhail Olgski, Captain Bronislaw Eliaszewicz, ${ }^{148}$ and Captain Jerzy Niezbrzycki, who was to accompany the evacuated members of the NTS on their way to Romania, and then also to meet Vladimir Baidalakov himself in Belgrade. ${ }^{149}$ It is worth mentioning that according to one report, the NTS suffered heavy casualties as a result of the September campaign; allegedly, it was already then that the agitation work among the Red Army soldiers began. ${ }^{150}$

146 According to Colonel Roman Umiastowski's account quoted by Bączkowski, Niezbrzycki was summoned, on 6 September 1939, to the chief of General Waclaw Stachiewicz's staff, to whom he reported "that Russia will undoubtedly act", W. Bączkowski, "Jerzy Niezbrzycki (R. Wraga) 1902-1968”, Niepodlełość, 23 (1990), p. 120.

147 P. Wieczorkiewicz, Łańcuch śmierci. Czystka w Armii Czerwonej 1937-1939, Warszawa, 2001, p. 687.

148 Captain B. Eliaszewicz, in September 1939 assigned to Division "East", went on to Romania, worked in Agency "R" in the Organizational Division, and then in the Intelligence Division, in the years 1941-1943 he headed Office no. 1 "Tandara" in Bucharest; Załacznik do sprawozdania, p. 386 , fn. 149.

149 “Падение Польши не прервало сотрудничества поляков с 'бледналицыми'. Маёр Бронислав Николай Ильяшевич [Cpt. Eliyashevich] был принят японским военным атташе в Букаресте на службу, а вместе с ним - Околович и Ольгский. Было решено возобновить отправки членов Союза в Россию, на сей раз путем перебраски через румыно-советскую границу". The author also claims that in 1940 Captain Eliaszewicz issued a Polish passport to him; Прянишников, Новопоколенцы, pp. 137 and 139; “В огне военных событий, до занятия немцами Польши, некоторые ответственные члены Союза пробились с польской территории с отступающими поляками в Румынию”, А.П. Столыпин, На службе, http:// ntsrs.ru/content/glava-4-nachalo-krupnyh-ispytaniy (access: 23 April 2015); Бржестовский, Свидание с родиной, р. 95.

150 “Там НТС и понес чувствительные потери в 1939 году, когда в Польшу двинулись части Красной армии. Некоторые члены Союза, не маскируясь, начали открыто вести пропаганду среди бойцов РККА и в конце концов были захвачены. Другие не сумели уйти в подполье, третьи попали в руки органов по доносам просоветски настроенных земляков. Но многие все-таки перебежали в зону немецкой оккупации. А небольшой части членов НТС удалось под видом рабочих пробраться в СССР - о чем руководство узнало только в 1941 году, во время немецкого наступления", Трушнович, К истории. 
During the Nazi occupation, Warsaw NTS led by Würgler was to co-operate with the Polish underground, ${ }^{151}$ engage in a double game with the Germans ${ }^{152}$ as well as in actions against the Soviet Union, ${ }^{153}$ as a result of which many of its members were arrested ${ }^{154}$ or killed, including Würgler and Brandt. ${ }^{155}$

\section{Summary}

The Promethean action was one of the factors undermining the Russians' willingness to co-operate with the Poles. The exception was a small group of associates of Dmitry Filosofov, the invaluable figure for the promotion of the idea of PolishRussian communication - they were among the few Russians who maintained links with the Promethean peoples. ${ }^{156}$ The Russians declaring their willingness to co-operate with other peoples of the former empire of the House of Romanov constituted a small margin on the Russian political scene. ${ }^{157}$ The most liberal

151 “Многие [NTS activists] имели липовые документы, которые выдавал контактировавший как с немцами, так и с польским подпольем в Варшаве, член Совета НТС А. Э. Вюрглер”, Б. Пушкарев, “НТС. Мысль и дело. К 80-летию НТС и 65-летию издательства 'Посев”,' Новый Журнал, 262 (2011), http://magazines.russ.ru/nj/2011/262/pu18.html (access: 22 April 2015). Members of the NTS were also to take part in the Warsaw Uprising; Исмагулова, Русская эмиграция, p. 351. It is worth noting that General Andrei Vlasov's soldiers, with whom some NTS members collaborated, did not take part in the suppression of the Warsaw Uprising; these were Bronisław Kaminski's troops of the Russian People's Liberation Army unrelated to it; Sukiennicki, Trzydzieści lat, p. 15.

152 Войцеховский, Эпизоды.

${ }^{153}$ It should be emphasized that this was happening in accordance with the ideological assumptions contained in the lecture delivered at the beginning of 1939 by the chairman of the NTS, Viktor Baidalakov: "Ни со Сталиным, ни с иностранными завоевателями, а со всем русским народом ... - Национальная Революция есть сегодня первое задание оборона страны. Она останется и тогда, когда вспыхнет война ... Россию спасет русская сила, на русской земле", quoted after: Прянишников, Новопоколенцы, p. 112.

154 Many of them, in the summer of 1944, were arrested by the Gestapo; J.J. Stephan, The Russian Fascists Tragedy and Farce in Exile, 1925-1945, London 1978, p. 30.

155 Their friend, Georgy Sokolov, since 1960 chairing the Executive Board of the Russian Cultural and Educational Society, survived; Mitzner, Warszawski "Domek w Kołomnie", p. 59.

156 Filosofov was present at the 9th anniversary of the establishment of the UPR army in May 1927 and at the annual ball of Ukrainian students in February 1926, the events bringing together Promethean activists; Wiszka, Emigracja ukraińska, pp. 193-194, 209.

157 A drastic example of "turning back" from the way of co-operation with other nations was the person of Boris Savinkov, who in his letters from the Lubyanka confessed, explaining his motives for going over to the Bolsheviks' side (it is possible that various investigative methods were used to make him "produce", for the needs of the Soviet Union, similarly to Yuriy [Yurko] Tyutyunnyk, materials shattering the sense of struggle against the communist rule. However low the credibility of these materials, it can be assumed that they reflect the problem of using by the Bolsheviks, in recruiting emigrants for co-operation, arguments of patriotic and nationalist nature); Б. Савинков - Д. Философову, 20 December 1924 г. Москва, in: Борис Савинков на Лубянке, р. 143. 
of them (except the aforementioned Filosofov), admitted only the possibility of establishing autonomy for non-Russian peoples; less often than others they questioned the Polish border, and after World War II, also that of the Baltic states.

From the Polish point of view, the Promethean activity did not have to exclude the support of the Russian anti-communist movement; but the fact is that most of the committed Prometheans rather limited themselves to the monitoring of activities of Russian organizations, rather than undertook co-operation with them. Ever since the "Trust" scandal, co-operation with the Russians was weakened and remodelled. Infiltrating the Russian circles, the Second Department came in contact with the New Generation movement. Co-operation with this movement was intensified in the second half of the 1930s, and this trend continued until the outbreak of World War II. It did not assume obtaining information of strategic nature (from the centres of power), but was intended to provide general information about the Soviet Union, which in the late 1920s was already very tightly isolated from the rest of the world (perhaps the aim was also to build the foundations of a sabotage and intelligence network in case of war with the USSR). In the internal arena, co-operation with the Russians was used to support people loyal to the government among them, as a result of which in the early 1930s the effect of consolidation of the Russian movement around the Polish state was achieved.

The person particularly actively co-operating with the Russian emigration on the grounds of internal policy was Tadeusz Hołówko, standing out, in this respect, from other Prometheans; Bronislaw Pieracki and especially Henryk SuchenekSuchocki were involved in the matters of the Russian minority. From among the circles of the Second Department such figures included Colonel Tadusz Schaetzel and Captain Jerzy Niezbrzycki, who, according to Włodzimierz Bączkowski, with time began to believe that the "fall of Moscow is possible only in case of resistance, «in the first place, of the Russian nation as the most populous one. The Russian people must become an ally of both the Poles and Ukrainians»". ${ }^{158}$ His collaboration with the New Generation movement may have contributed to the formulation of this view, which could also be indicated by Brzhestovskiy's account cited above.

Their negative attitude to both the Third Reich and the USSR, which allowed to find a common denominator with the Polish state, may have played an important role in establishing contact with the New Generation movement.

The question of the main objective of co-operation with NTS members remains unanswered. Was it merely all about juxtaposing anti-Polish youth movements with a pro-Polish association, obtaining information and committing possible acts of sabotage, not only in western Russia, but also in the Far East, ${ }^{159}$ or also about creating a permanent pro-Polish lobby and a group that could be used in case of war with the USSR?

158 Bączkowski, Jerzy Niezbrzycki, p. 118.

159 Грибков, Жуков, Ковтун, Особый штаб “Россия”, р. 92. 
Another issue which needs examination is the question of how the New Generation movement was inspired by the Second Department, and to what extent it was natural collaboration, undertaken on the basis of an independent decision of NSRM authorities. The acquisition of this movement allowed to create among part of the emigration youth a good image of Poland, and - through the development of the organization - contributed to the weakening of the influence of pro-Soviet and pro-German youth organizations with a negative attitude towards the Polish state, competing with the NTS, a movement which emerged victorious, and as the only one continually expanded its structures, continuing operations after 1945, until the collapse of the USSR.

It should be emphasized that, apart from the NTS, also other organizations associated with the Eurasian movement, such as "Impierskiy Soyuz" and wellknown Russian activists such as Professor Pyotr Struve or, in Poland, Sergey Voytsiekhovsky and Andrei Surkov, were sounded out.

The decision to engage in co-operation with the NTS proved to be the Second Department's great "investment", even if none of those in charge of the matter had such intentions. This is evidenced by the loyalty that NTS members demonstrated towards the Poles in September 1939, and also during the Second World War, as well as after it, as we find out from many memories.

The co-operation established in the 1930s has paid off until present day as the NTS has survived the collapse of the Soviet Union and developed its activities in the country. The organization may be given credit not only for their actions to promote the ideas of the Russian emigration, such as the film "Admiral", but also for lectures on the crimes committed by the USSR, including the murder of Polish officers in Katyń. ${ }^{160}$

\section{Abstract}

The article spans the period of 1926-1935, but the presentation of the Polish state policy towards chosen Russian exiles is set in the context of the Polish-Russian co-operation from 1920 to the 1926 May Coup and concludes with an epilogue about Jerzy Niezbrzycki's cooperation with the members of the Polish branch of the NTS (The National Alliance of Russian Solidarists) in the second half of the 1930s. The author explores the questions of attitudes of the Second Division of the General Staff of the Polish Army and the Ministry of Internal Affairs (occasionally engaged at the same time in Promethean work and contacts with leading members of Russian emigrants in Poland and abroad) towards the Russian emigration. Thus, the article is to answer the questions of the significance of this diaspora to the Polish authorities and of the mechanisms of enlisting their support for the Polish state.

The author has reached following conclusions: from the Polish perspective, Promethean activities did not automatically exclude the support for the Russian anti-communist movement, although in fact in the case of a majority of Prometheans it was limited to monitoring of activities of Russian organisations rather than cooperating with them. Contrary to opinions

${ }^{160}$ http://magazines.russ.ru/nj/2011/262/pu18.html (access: 6 May 2015). 
of some researchers, the cooperation with the Russians was not broken after the MOCR-Trust was revealed at the turn of the 1927, but was re-modelled. Often, the purpose of maintaining contacts with the Russians was to replace the activists inconvenient to the authorities with those who were loyal to them; such a policy brought about in the early 1930s the effect of consolidation of the Russian movement around the Polish state, and minimised German and Soviet impact on it.

The study is based on the analysis of the Russian press, memories, published documents and correspondence, as well as materials hold in the Central Archives of Modern Records in Warsaw, Archives of the Institute of National Remembrance and the online collection of the Józef Piłsudski Institute in New York and International Institute of Social History at Amsterdam.

\section{Bibliography}

\section{Archives}

Archiwum Akt Nowych [The Archives of New Records], Warsaw, the Ministry of Internal Affairs.

Archiwum Instytutu Pamięci Narodowej [The Archives of the Institute of National Remembrance], Warsaw, BU 1572/1017, Employees of Agency no. 2 of the Second Department of the General Staff. Communication no. 5 of the Main Directorate of Information of the Ministry of National Defence; BU 1572/1165, the Second Department of the General Staff of the Polish Armed Forces, Division "East" in the years 1929-1939 [...]. Compiled by Colonel Gajewski of the Main Directorate of Information of the Ministry of National Defence, lists of foreign offices; BU 2602/1440, the Second Directorate of the General Staff of the Polish Armed Forces in Warsaw. Portfolio I, the activity of the Second Department of the General Staff in the years 1933-1939, reports; BU, 2386/16886, the leadership of WSW [Internal Military Service] 1960-1963.

Józef Piłsudski Institute of America in New York, Ukrainian Military Mission in Poland (on-line collection).

International Institute of Social History, Amsterdam, Boris Viktorovich Savinkov Papers (on-line collection).

\section{Newspapers and magazines}

Meu, Warsaw 1934-1935

Молва, Warsaw 1932-1934

Новая Россия, Vilnius 1926-1928

Свобода, Warsaw 1920

Виленское утро, Vilnius 1926

За Свободу!, Warsaw 1920-1932

\section{Published sources and literature}

Account of Borys Kowerda, http://zhurnal.lib.ru/g/gorbunow_g_a/koverda.shtml (access: 5 May 2015).

Backer R., Międzywojenny eurazjatyzm. Od intelektualnej kontrakulturacji do totalitaryzmu?, Łódź, 2000. 
Bączkowski W., “Jerzy Niezbrzycki (R. Wraga) 1902-1968”, Niepodległość, 23 (1990).

Besançon A., Święta Ruś, Warszawa, 2012.

Borzęcki J., Pokój ryski 1921 roku i kształtowanie się międzywojennej Europy Wschodniej, Warszawa, 2012.

Bruski J.J., Między prometeizmem a Realpolitik. II Rzeczpospolita wobec Ukrainy sowieckiej 1921-1926, Kraków, 2010.

Czapski J., Świat w moich oczach, Ząbki-Paris, 2001.

Czapski J., Wyrwane strony, ed. Joanna Pollakówna, Warszawa, 1993.

Dokumenty i materiały do historii stosunków polsko-radzieckich, vol. 3, eds. N. Gąsiorowska-Grabowska, I.A. Chrienow; vol. 4, eds. T. Cieślak, I.A. Chrienow, Warszawa, 1964-1965.

Dokumenty z dziejów polskiej polityki zagranicznej 1918-1939, eds. T. Jędruszczak, M. Nowak-Kiełbikowa, vol. 1, Warszawa, 1989.

Dryblak Ł., "Inspiracja i formy współpracy polskich instytucji państwowych z wydawcami i redakcjami pism rosyjskich w latach 1919-1935 - zarys problematyki”, Dzieje Najnowsze, 48 (2016), no. 1.

Drymmer W.T., “Trust”, Kultura, 11 (Paryż 1965).

Durrant J.S., B. Sawinkow w Warszawie - z pamiętników D. W. Fiłosofowa and Zapomniany warszawianin, from the archives of Kultura, in Maisons-Laffitte (typescript; I was given access to the photocopies by courtesy of Professor Andrzej Nowak).

Gippius Z., Dzienniki petersburskie. Dziennik warszawski, transl. and ed. H. Chłystowski, Warszawa, 2010.

Heller M., "List Borysa Sawinkowa do marszałka Piłsudskiego", in: Sowietskij Sojuz. Wybór, Wrocław, 1989, pp. 79-90.

Karpus Z., Wschodni sojusznicy Polski w wojnie 1920 roku. Oddziały wojskowe ukrainskie, rosyjskie, kozackie i białoruskie w Polce w latach 1919-1920, Toruń, 1999.

Kornat M., "Idea prometejska a polska polityka zagraniczna (1921-1939/1940)", in: Ruch prometejski i walka o przebudowę Europy Wschodniej (1918-1940), ed. M. Kornat, Warszawa, 2012.

Kornat M., "Instytut Naukowo-Badawczy Europy Wschodniej w Wilnie (1930-1939) i jego wkład w rozwój polskiej sowietologii”, Kwartalnik Historyczny, 107 (2000), no. 3.

Kornat M., "Tadeusz Schaetzel (1891-1971) nota biograficzna”, Pressje, 2010, nos. 22-23.

Kropp P., Sekrety wywiadu francuskiego, Warszawa, 1999.

Libera P., "Ewolucja ruchu prometejskiego w okresie międzywojennym", in: Ruch prometejski i walka o przebudowę Europy Wschodniej (1918-1940), ed. M. Kornat, Warszawa, 2012.

"Listy Dymitra Fiłosofowa do Mariana Zdziechowskiego", comp. and ed. P. Ławriniec, Zeszyty Historyczne, 168 (Paris, 2008).

Materski W., Na widecie. II Rzeczpospolita wobec Sowietów 1918-1943, Łódź, 2005.

Mereżkowski D., "Józef Piłsudski", Twórczość, 52 (1996), no. 4.

Michniewicz W., Wielki bluff sowiecki, Chicago, 1991.

Mitzner P., Warszawski "Domek w Kołomnie”, Warszawa, 2014.

Mitzner P., Warszawski krąg Dymitra Fiłosofowa, Warszawa, 2015.

Nowak A., "Dymitr Fiłosofow: dyskusja z polską 'mickiewiczologią' czy z polskim kompleksem?", in: Akademie nauk, uniwersytety, organizacje nauki, polsko-rosyjskie relacje $w$ sferze nauki XVIII-XX w., ed. L. Zasztowt, Warszawa, 2013.

Nowak A., Jak rozbić rosyjskie imperium. Idee polskiej polityki wschodniej (1733-1921), Warszawa, 1991.

Nowak A., Polska i trzy Rosje. Studium polityki wschodniej Józefa Piłsudskiego (od kwietnia 1920 roku), Kraków, 2001 (revised edition: 2014).

Paduszek K., Polski wywiad wojskowy na Rosję Sowiecką/Związek Sowiecki w latach 1921-1927, Warszawa, 2014, doctoral dissertation (typescript), Library of the Historical Institute, University of Warsaw. 
Pipes R., Struve. Liberal on the Right, 1905-1944, London, 1980.

"Polityka narodowościowa władz polskich wobec emigracji i mniejszości rosyjskiej w latach 1926-1935. Wybór dokumentów”, ed. Ł. Dryblak, Przegląd Wschodni, 14 (2015), no. 1.

"Rosyjski łącznik Naczelnika - wybór listów Karola Wędziagolskiego do Piotra Wandycza", ed. A. Nowak, Arcana, 70/71 (2006).

Sasiedzi wobec wojny 1920 roku, ed. J. Cisek, London, 1990.

Skrunda W., "Rosyjska "Mniejszościowa" Organizacja Młodzieżowa w Polsce międzywojennej (ROM). Okoliczności powstania”, Studia Rossica, 5 (1997).

Snyder T., Tajna wojna Henryk Józewski i polsko-sowiecka rozgrywka o Ukrainę, Kraków, 2008. Spence R.B., Renegade on the Left, New York, 1991.

Stanisław Patek. Raporty i korespondencja z Moskwy (1927-1932), ed. M. Gmurczyk-Wrońska, Warszawa, 2010.

Stanisławski W., “'Rycerz przegranej sprawy”? Kontakty Dymitra Fiłosofowa z polskimi elitami kulturalnymi”, in: Emigracja rosyjska losy i idee, eds. R. Backer, Z. Karpus, Łódź, 2002.

Stanisławski W., Myśl polityczna emigracji rosyjskiej w II Rzeczpospolitej: interpretacje przeszłości $i$ koncepcje polityczne, doctoral dissertation (typescript), Library of the Historical Institute, University of Warsaw.

Stephan J.J., The Russian Fascists tragedy and Farce in Exile, 1925-1945, London, 1978.

Stołypin A., Cesarstwo i wygnanie, transl. T. Hertz, Warszawa, 1998.

Sukiennicki W., Trzydzieści lat emigracji rosyjskiej, London, 1949.

Ulatowski Ł., Niezbrzycki - wybrane aspekty biografii wywiadowczej kierownika Referatu "Wschód", w:http://www.academia.edu/3459067/Lukasz_Ulatowski_Niezbrzycki_wybrane_ aspekty_biografii_wywiadowczej_kierownika_Referatu_Wschod.

Wędziagolski K., Pamiętniki, wojna i rewolucja, kontrrewolucja, bolszewicki przewrót, warszawski epilog, Warszawa, 2007.

Wieczorkiewicz P., Łańcuch śmierci. Czystka w Armii Czerwonej 1937-1939, Warszawa, 2001. Wiszka E., emigracja ukraińska w Polsce 1920-1939, Toruń, 2004.

“Załącznik do sprawozdania z działalności Oddziału II Sztabu Głównego”, prep. T. Dubicki, A. Suchcitz, in: Wywiad i kontrwywiad wojskowy II RP, vol. 1, ed. T. Dubicki, Łomianki, 2010, pp. 342-393.

Байдалаков В.М., Да возвлечится Россия. Да гибнут наши имена... Воспоминания председатела НТС 1930-1960 г2., Москва, 2002.

Борис Савинков на Лубянке. Документы, еd. А.Л. Литвин, Москва, 2001.

Бржестовский М., “Свидание с родиной”, in: От зарубежья до Москвы. Нароно-Трудовой Союз (НТС) в воспоминаниях и документах 1924-2014, еd. В. Сендеров, Москва, 2014, pp. 90-104.

Войцеховский С.Л., Эпизоды, London-Kanada 1978, http://www.dk1868.ru/history/voytzexov. htm\#z151 (access: 14 January 2014).

Грибков И.В.,. Жуков Д.А, Ковтун И.И., Особый штаб “Россия”, Москва, 2011.

Дивнич Е., Нам пора объясниться!', New York, 1968.

“Из переписки Д.В. Философова. 1920-1932”, Наме Наследие, 63-64 (2002), http://www. nasledie-Rus.ru/podshivka/6407.php (access: 14 January 2015).

“Из протоколов допросов лидера Национально-Трудового Союза Нового Поколения М.А. Георгиевского", in: Политическая история русской эмигращии 1920-1940 г2. Документы и материаль, еd. А.Ф. Киселев, Москва, 1999, http://www.russky.com/ history/library/emigration/emigration3.htm\#290 (access: 27 April 2015).

Исмагулова Т.Д., "Русская эмиграция в Польше (Владимир Бранд - поэт и воин 'русской Варшавы’)”, in: Зарубежная Россия 1917-1939 г2., еd. В. Ю. Черняев, Санкт-Петербург, 2003. 
Окороков А.В., Русская эмиграция, Москва, 2003.

Прянишников Б., Новопоколенц,ьl, Мэриленд, 1986.

Сочинения русского периода, vol. 1: Стихотворения и поэмы, ed. Л. Флейшман, Москва, 2011.

Столыпин А.П., На службе России. Очерки по истории НТС, Frankfurt am Main, 1986, http://ntsrs.ru/content/p-stolypin-na-sluzhbe-rossii (access: 30 May 2014).

Струве П.Б., Дневник Политика (1925-1935), Москва-Париж, 2004.

Трушнович Я., “К истории Нородно-Трудового Союза”, Посев, 7 (2000), http://www.posev. ru/files/nts-about/ne7006.htm (access: 9 April 15).

Флейшман Л., Абызов Ю., Равдин Б., Русская печать в Риге: из истории газеть “Сегодня" 1930-х годов, vols. 1-5, Stanford, 1997.

Eukasz Dryblak, doctoral student in the Institute of History of the Polish Academy of Sciences. Research interests: Polish-Russian relations, Russian exile, military history, ethnic policy of the Second Polish Republic (lukaszdryblak7@wp.pl). 